\title{
Testing and Disposal Strategy for Secondary Wastes from Vitrification of Sodium-Bearing Waste at Idaho Nuclear Technology and Engineering Center
}

A. K. Herbst

January 2002

Idaho National Engineering and Environmental Laboratory Bechtel BWXT Idaho, LLC 


\title{
Testing and Disposal Strategy for Secondary Wastes from Vitrification of Sodium-Bearing Waste at Idaho Nuclear Technology and Engineering Center
}

\author{
A. K. Herbst
}

Published January 2002

Idaho National Engineering and Environmental Laboratory Idaho Falls, Idaho 83415 


\begin{abstract}
The Idaho National Engineering and Environmental Laboratory (INEEL) is considering vitrification to process liquid sodium-bearing waste. Preliminary studies were completed to evaluate the potential secondary wastes from the melter off-gas cleanup systems. Projected secondary wastes comprise acidic and caustic scrubber solutions, HEPA filters, activated carbon, and ion exchange media. Possible treatment methods, waste forms, and disposal sites are evaluated from radiological and mercury contamination estimates.
\end{abstract}




\section{SUMMARY}

The High-Level Waste Program is considering vitrification of the liquid sodium-bearing waste stored at the Idaho Nuclear Technology and Engineering Center, which is part of the Idaho National Engineering and Environmental Laboratory (INEEL). Several secondary wastes are anticipated from the melter off-gas treatment system, such as acidic and caustic scrubber solutions, HEPA filters, activated carbon, and ion exchange media. These wastes are expected to be designated as mixed low-level wastes. Scoping studies were completed to evaluate possible disposal paths for these wastes. Radiological and land disposal regulations as well as individual site waste acceptance criteria were considered to anticipate necessary treatment methods, waste forms, and disposal sites for each waste stream.

In general, the radiological content of all secondary wastes can be managed and disposal sites are available. These sites are as follows:

- The Hanford Site (accepts Category 1 and 3 mixed low-level waste)

- The Nevada Test Site (is seeking a mixed waste license for both Class A and Class $\mathrm{C}$ wastes) and

- Envirocare of Utah (accepts Class A mixed low-level waste).

Land disposal regulations may present more of a challenge for secondary waste disposal. In the vitrification process, nearly all mercury exits the melter and enters the off-gas system; thus, the mercury in the sodium-bearing waste will find its way to the secondary wastes. Under the baseline flowsheet, both the scrubber grout and the activated carbon may exceed $260 \mathrm{mg} / \mathrm{kg}$ for mercury. Secondary waste forms must demonstrate leach resistance (TCLP). Mercury amalgamation equivalency agreements may be needed to allow land disposal. Additionally, the RCRA listed waste codes must be accepted at the disposal sites. At present, the Hanford and Nevada sites do not accept the hydrofluoric acid code (U-134).

The INEEL strategy for new processes is to determine secondary waste disposal paths prior to generation of such wastes. If a disposal path is not possible, the process design will be evaluated for alternative solutions. 


\section{NOMENCLATURE}

\author{
Alkaline Grout \\ Blast Furnace Slag
}

Calcination

Cement

CsIX

Denitration

Fly Ash

GAC

Grout

HEPA Filter

Leaching
A grout formulation where the waste is rendered basic $(\mathrm{pH}>$ 12) and mixed with a 9:1 blend of blast furnace slag and portland cement.

A finely ground non-metallic waste product developed in the manufacture of pig iron, consisting basically of a mixture of lime, silica, and alumina, the same oxides that make up portland cement, but not in the same proportions or forms.

The process of converting a liquid to a solid granular product called calcine.

Refers to type I/II portland cement.

Removal of cesium from a liquid via an ion exchange media.

Thermal process to destroy the nitrate content of the waste.

A pozzolan of finely divided residue that results from the combustion of ground or powdered coal. Class $\mathrm{C}$ fly ash may contain $10 \%$ lime, has cementitious properties, and reacts with water to form a solid. Class F fly ash does not use water and aids in grout flow.

Granulated activated carbon.

A mixture of portland cement, other powdered additives, waste, and water. It may contain fine-grained sand and does not include large aggregate material. For this study, grouting is the process of solidifying and stabilizing low-level waste in cement based materials.

High efficiency particulate air filter.

The process whereby a liquid agent will dissolve hazardous materials within a waste mass and transport these materials through the mass and beyond. The most widely used laboratory leaching test is the TCLP (Toxic Characteristic Leaching Procedure) specified by the EPA in several regulations. For many treated and untreated wastes, the results of this test determines whether the EPA considers the material toxic or not. 
Low-Activity Waste

NGLW

Portland Cement

Pozzolan

Solidification

Stabilization

Waste Form

Waste Loading

Vitrification
Low-level waste derived from the solvent extraction, ion exchange, and chemical extraction separation processes on the tank farm sodium-bearing waste and on the dissolved calcines.

Newly generated liquid waste -- low-level waste projected to be produced that is not part of the existing tank farm inventory. Sources are the process equipment waste system, decontamination solutions, and filter leach solutions.

The product obtained by pulverizing clinker consisting essentially of hydraulic calcium silicates.

A siliceous or siliceous and aluminous material that reacts with liquid calcium hydroxide in the cement gel to form compounds possessing cementitious properties.

The process of producing from liquid, sludge, or loose solids a more or less monolithic structure having some integrity. Occasionally, solidification may refer to the process that results in a soil-like material rather than a monolithic structure. Solidification does not necessarily reduce leaching of hazardous materials. However, when a waste is solidified, its mass and structure are altered, decreasing migration of solutions within the mass.

Generally refers to a purposeful chemical reaction that is carried out to make waste constituents less leachable. This is accomplished by chemically immobilizing hazardous materials or reducing their solubility by a chemical reaction.

The final product for long-term storage. This includes the solidified/stabilized waste as well as the container. The waste form must pass extensive qualification testing prior to release for storage.

The mass weight percent of the waste in the total mass of the final waste form.

The process of placing waste material in a glass form. This is a thermal process where the waste material is placed in a melter with glass forming material (chemicals or frit), then heated together, poured into a storage container, and cooled to a solid form. 


\section{CONTENTS}

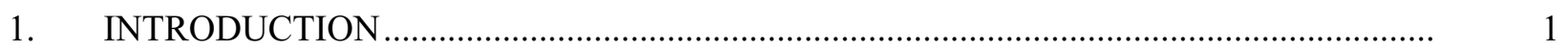

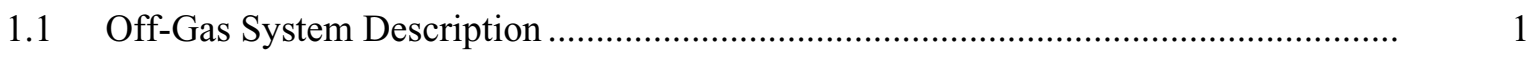

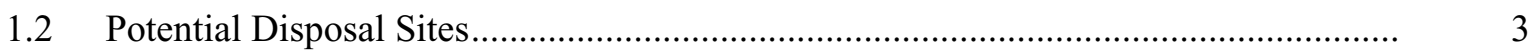

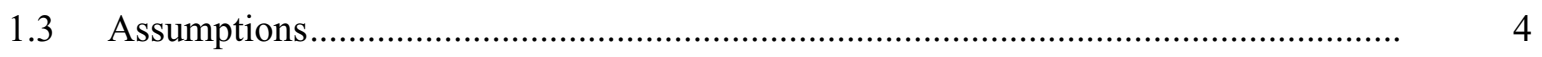

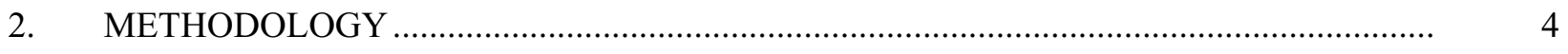

3. PROJECTED DISPOSAL PATHS ….................................................................... 5

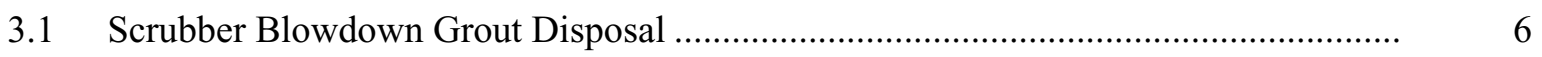

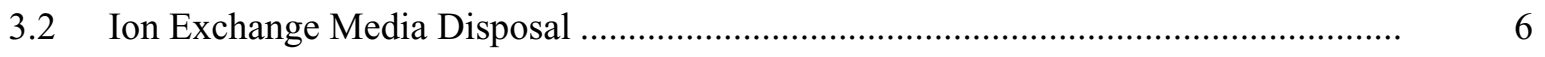

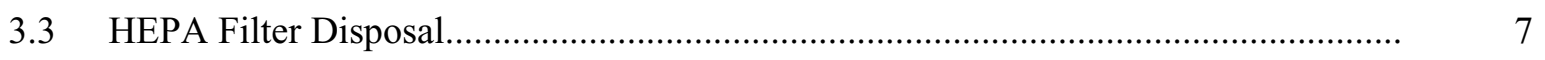

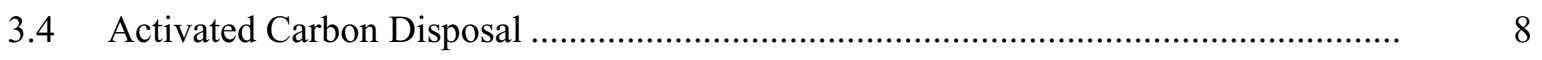

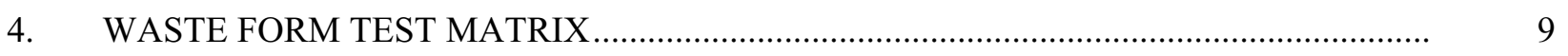

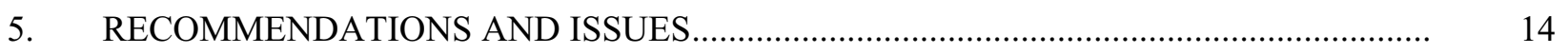

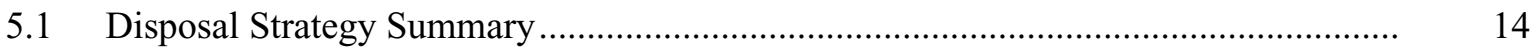

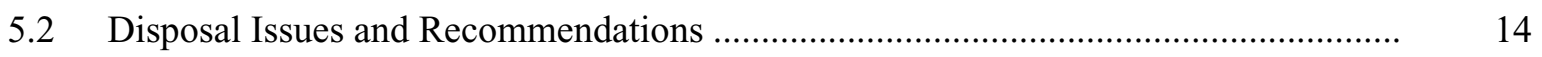

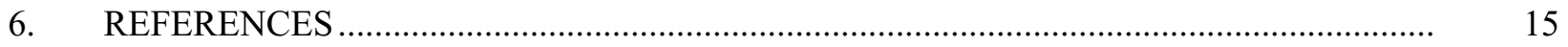

\section{FIGURES}

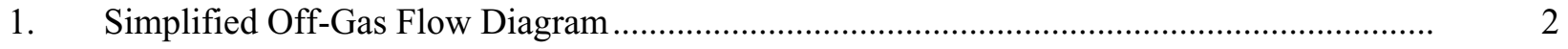

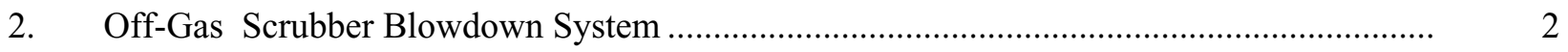

\section{TABLES}

1. SBW Vitrification Flowsheet Secondary Waste Results............................................... 5

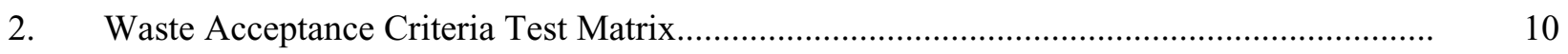




\section{APPENDICES}

A. Secondary Waste Characterization

B. Waste Acceptance Criteria Summaries

C. Radiological Estimates

D. Mercury Concentrations 


\section{TESTING AND DISPOSAL STRATEGY FOR SECONDARY WASTES FROM VITRIFICATION OF SODIUM-BEARING WASTE AT THE IDAHO NUCLEAR TECHNOLOGY AND ENGINEERING CENTER}

\section{INTRODUCTION}

The Idaho Nuclear Technology and Engineering Center (INTEC) High-Level Waste Program will prepare liquid sodium-bearing waste and calcined solids for eventual disposal. Several alternative disposal processes have been explored for these wastes. During fiscal year 2001, direct vitrification of sodium-bearing waste was studied. The potential secondary wastes resulting from the vitrification off-gas cleanup operations are identified herein in conjunction with their associated disposal strategies and waste form testing requirements.

The vitrification process uses a glass melter to immobilize the sodium-bearing waste (SBW). As part of this process, the off-gas requires a cleanup system that utilizes liquid scrubbers, high efficiency filters, and activated carbon to clean the off-gas prior to release to the environment (Figure 1). These cleanup actions result in secondary waste production and subsequent need for waste treatment and disposal. Initial scoping studies evaluated the feasibility of treatment and disposal of scrubber blowdown solutions, ion exchange media, filters, and activated carbon. ${ }^{1}$

A SBW vitrification baseline flowsheet and mass balance were developed during fiscal year $2001^{2}$ and updated in mid-November, $2001^{3}$. The latter flowsheet and mass balance form the basis for this secondary waste evaluation. It is anticipated that $49 \mathrm{~m}^{3}$ of grouted scrubber waste, $6.3 \mathrm{~m}^{3}$ of spent filters, $54 \mathrm{~m}^{3}$ of activated carbon, and $5.2 \mathrm{~m}^{3}$ ion exchange media will be produced as secondary wastes during the 2 years of processing the SBW inventory. It is expected these wastes will be designated as mixed low-level wastes.

\subsection{Off-Gas System Description}

The off-gas treatment system consists of acidic and caustic scrubbers, filters, activated carbon, and a unit to reduce oxides of nitrogen as noted in Figure 1. The off-gas from the melter is immediately cooled in a film cooler at a flowrate of $1915 \mathrm{~m}^{3} / \mathrm{hr}$; air $\left(145 \mathrm{~m}^{3} / \mathrm{hr}\right)$ is then added to provide pressure control. The off-gas is next quenched and then scrubbed in an acidic solution, followed by a high efficiency mist eliminator to remove the bulk of particulate carryover from the melter. At this point, the off-gas flowrate is $2060 \mathrm{~m}^{3} / \mathrm{hr}$. The scrubber is followed by a set of high efficiency particulate air (HEPA) filters. Next, any oxides of nitrogen are destroyed by thermal combustion in a Noxidizer $_{\mathrm{TM}}$ unit. Combustion gases, quench water, and reoxidation air added in the Noxidizer $_{\mathrm{TM}}$ increase the off-gas flowrate to $3360 \mathrm{~m}^{3} / \mathrm{hr}$. The off-gas is again scrubbed in a caustic solution to remove most of the acid gases. This is followed by a demister and a bed of granulated, activated carbon to clean the off-gas and remove any remaining mercury. Finally, the off-gas passes through another set of HEPA filters and is released to the atmosphere at $3360 \mathrm{~m}^{3} / \mathrm{hr}$.

Since the acidic scrubber solution may be highly contaminated with particulate radionuclides, it is planned to recycle most of this solution to the melter. The updated flowsheet predicts $20.6 \mathrm{~L} / \mathrm{hr}$ to be recycled to the melter and about $1.4 \mathrm{~L} / \mathrm{hr}$ to be waste blowdown solution (Figure 2). This acidic blowdown will then undergo neutralization, filtration, and cesium removal (CsIX) utilizing ion exchange media such as crystalline silicotitanate (CST) to reduce the gamma radiation levels of the solution. The filter solids will be combined with the acidic scrubber recycle solution to the melter. The acid scrubber blowdown (CsIX effluent, 1.7 L/hr) 


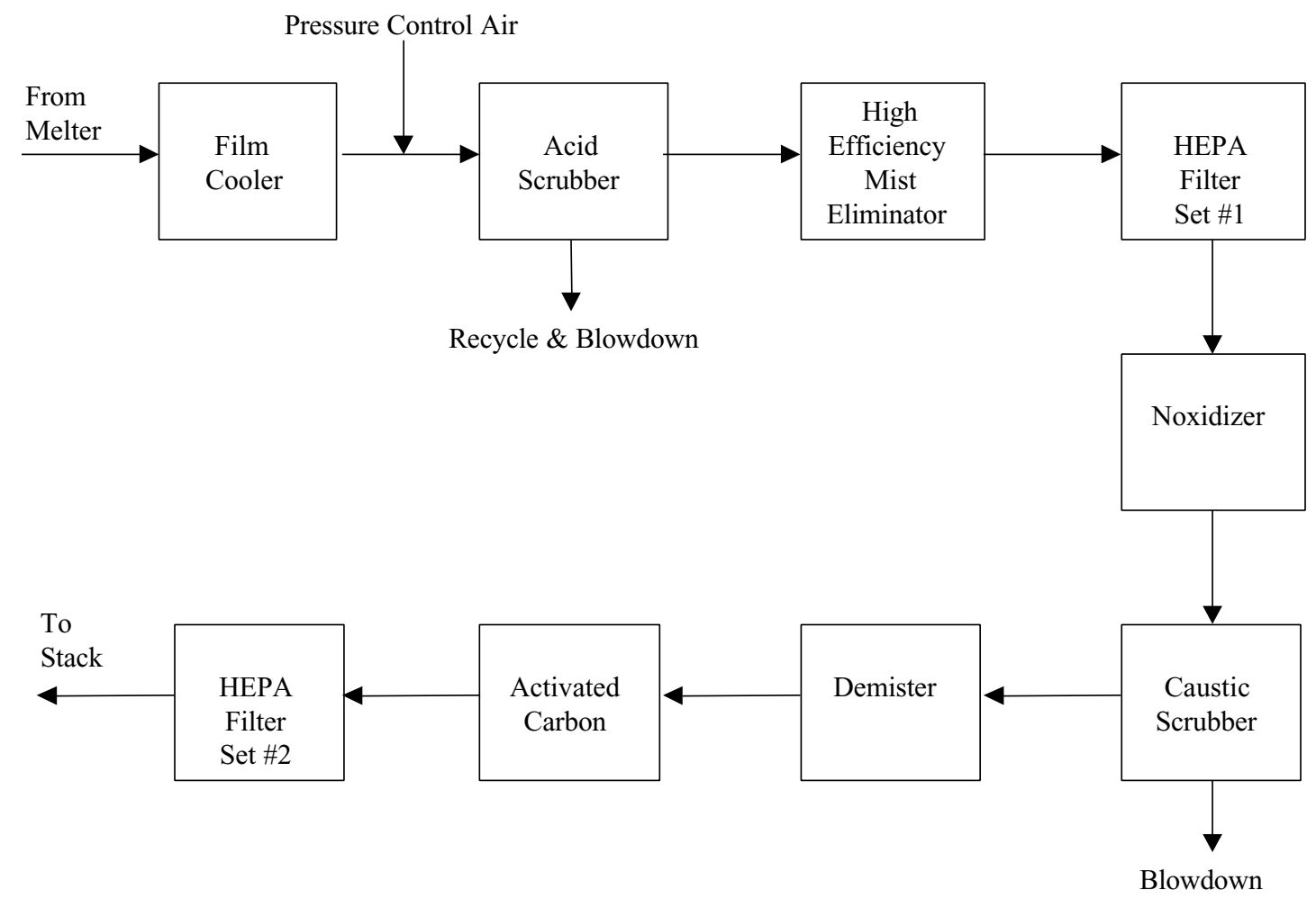

Figure 1. Simplified Off-Gas Flow Diagram

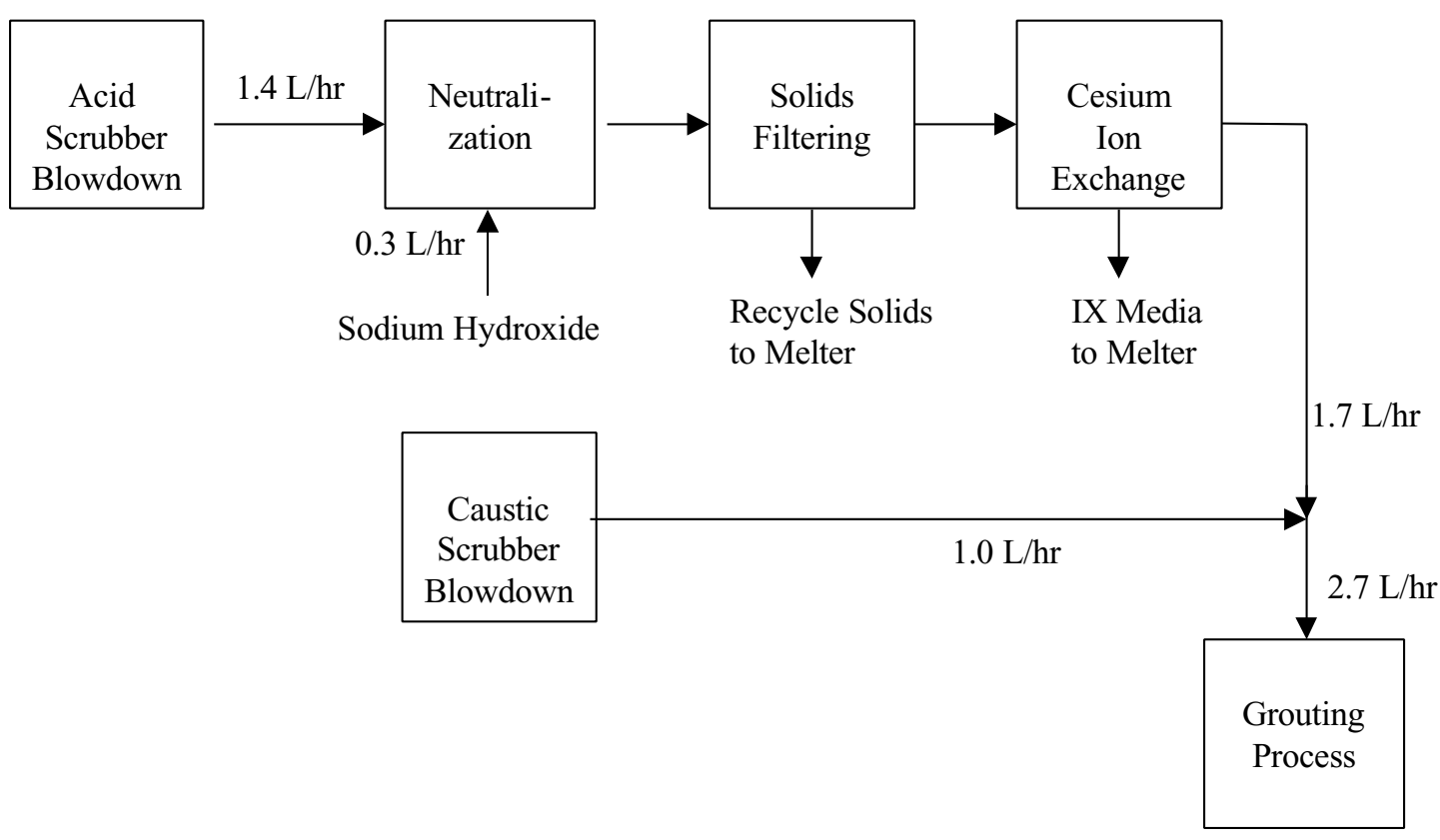

Figure 2. Off-Gas Scrubber Blowdown System 
will then be combined with the caustic scrubber blowdown $(1.0 \mathrm{~L} / \mathrm{hr})$ to yield about $2.7 \mathrm{~L} / \mathrm{hr}$ to be grouted. The combined solution is expected to be caustic and can be directly grouted with minimal pretreatment.

The HEPA filter set \#1 (Figure 1) is expected to be changed out every 6 months during the 2 year SBW campaign. The carbon bed and ion exchange media should last the 2 years. For final HEPA filter set \#2, it is planned to change out the prefilters every 6 months while the main HEPA filters in these banks should remain in place for the 2 years.

\subsection{Potential Disposal Sites}

Four disposal sites are available to the INEEL for disposal of secondary waste. These are the Hanford Site, Nevada Test Site (NTS), Envirocare of Utah, and the Radioactive Waste Management Complex (RWMC) at the INEEL. The RWMC is not considered a potential site since it is not designated as a long-term mixed waste disposal site. The Hanford Site has been designated as the Department of Energy (DOE) mixed waste disposal site and is now receiving waste, although little from out of state at present. The Nevada Test Site at present will accept only low-level waste; however, NTS has applied for a mixed waste license that should be approved in 2002. Envirocare of Utah will accept mixed low-level Class A waste, but they decided to withdraw their application for Class $\mathrm{C}$ waste.

The radioactive characterization of the waste must be provided to all sites. The concentration of each specific radionuclide cannot exceed its specified disposal limit. In addition, all sites have a sum of fractions rule that must be met for the combination of all radionuclides. This rule requires the concentration of each radionuclide be divided by the concentration limit to yield a fraction, then all these fractions are summed. The total sum of fractions must be less than 1.0. This prevents excessive radiation in the waste that would be caused by having several radionuclides near their concentration limits. The sum of fractions rule is used as a determining factor as to the category or class of the waste.

Under the Resource Conservation and Recovery Act (RCRA) regulations, the SBW listed waste codes (F001, F002, F003, and U134) would be carried by all of the secondary wastes. Envirocare will accept all of these codes, whereas Hanford and NTS do not accept the hydrofluoric acid (U134) listed code. As such, any waste going to Hanford or NTS will need a waiver or delisting agreement.

For hazardous metals, the disposal sites accept the toxicity characteristic leaching procedure (TCLP) at Universal Treatment Standards ${ }^{4}$. For all secondary wastes, it is anticipated that minor amounts of cadmium, chromium, and lead will be present; however, since nearly all the mercury exits the melter into the off-gas system, some of the wastes will be high for mercury (anticipated to be greater than $260 \mathrm{mg} / \mathrm{kg}$ ). This will require that the waste forms pass TCLP for mercury and a best demonstrated available technology (BDAT) equivalency may be required with the disposal site. In current discussions with Hanford, only the TCLP is required.

All the sites impose the no free liquid rule. Furthermore, none have specific physical strength requirements for grouted waste or other solids. All sites accept the standard 55 gallon waste drum for most waste classes. For high radiation wastes, Hanford requires use of a high integrity container (HIC). 


\subsection{Assumptions}

Assumptions used in developing the secondary waste disposal strategies are:

- Acidic and caustic combined scrub density is $1300 \mathrm{~g} / \mathrm{L}$

- Combined scrub grout density is $1800 \mathrm{~kg} / \mathrm{m}^{3}$ at $35 \mathrm{wt} \%$ waste loading

- The HEPA filter media density is $110 \mathrm{~kg} / \mathrm{m}^{3}$

- The HEPA filter density with the frames is $1000 \mathrm{~kg} / \mathrm{m}^{3}$

- The HEPA filter volume is based on 4 banks of a 24 in. X 24 in. X 6 in. prefilter followed by 2 filters 24 in. X 24 in. X 12 in. This calculates to $1.13 \mathrm{~m}^{3}$

- Interim filters (HEPA Set \#1) are changed out 4 times during the 2 years of operations

- For the final filters (HEPA Set \#2), the prefilters will be changed out 4 times during the 2 years of operation and the HEPA filters behind the prefilters will remain in place during the 2 years of operation

- Since the final filter bank prefilters are changed out 4 times, it is assumed that $99 \%$ of the contamination is on the 16 prefilters and $1 \%$ on the final 8 HEPAs

- No compaction of filters is assumed in contamination concentrations

- Sulfur impregnated activated carbon is used and remains in place for the 2 years of operations

- The activated carbon bed density is $550 \mathrm{~kg} / \mathrm{m}^{3}$

- Ion exchange media remains in place during the 2 years

- Ion exchange media density is $640 \mathrm{~kg} / \mathrm{m}^{3}$

- Operations are based on 24 hours per day, 200 days per year, for 2 years.

\section{METHODOLOGY}

The SBW vitrification flowsheet and mass balance dated November 15, 2001, for the "Total" waste was used to evaluate the secondary waste concentrations. The "Total" concentration mass balance is the projected blended combination of all wastes collected until 2012 from both the SBW and Newly Generated Liquid Waste (NGLW). A waste characterization compilation is shown in Appendix A. These secondary waste concentrations were compared against the waste acceptance criteria (WAC) for the various disposal sites. Detailed WAC summaries for each secondary waste are found in Appendix B. The calculations include the individual radionuclides compared to the WAC limit, the transuranic (TRU) content, and the sum of fractions. These resulting values are presented for the Hanford WAC Category 1 and 3, Nevada Test Site WAC using the Nuclear Regulatory Commission (NRC) WAC Class A and C, and Envirocare of Utah WAC. Unless noted, the mass balance presents the radionuclide concentration in Curies per cubic meter $\left(\mathrm{Ci} / \mathrm{m}^{3}\right)$. The grout density is used to calculate the TRU concentration in nano-Curies per gram (nCi/g) and the Envirocare concentration in pico-Curies per gram (pCi/g).

The mass balance spreadsheet reported the combined scrubber grout radionuclide concentrations directly. For the other secondary wastes, the difference between the inlet unit operation and the outlet unit operation were subtracted from each other and multiplied by the flow rate and total time of operation to obtain the concentration build up. This calculation was performed for the interim HEPA filters between the High Efficiency Mist Eliminatory (HEME) outlet and the Noxidizer ${ }_{\mathrm{TM}}$ inlet. For the HEPA set \#1 filters, the concentrations were divided by 4 to allow for the 4 change-outs during operations. The final HEPA set \#2 filter radionuclide concentration was obtained by using the outlet concentrations from the activated carbon and the stack release concentrations. The buildup on the activated carbon bed was determined by subtracting the concentrations at the outlet of the demister and the carbon bed outlet and then multiplying by the off-gas flowrate at that point and the total operating time. The cesium concentration on the ion exchange media was found in a likewise manner. 
For these scoping studies, only a limited number of radionuclides were used as noted in Appendix B. The nine radionuclides were found to be the major contributors to the sum of fractions and TRU content. However, when the waste is disposed, all radionuclides must be accounted for in the sum. Thus, if the preliminary sum is 0.9 , the final sum may exceed the limit of 1.0 due to the addition of the all the other radionuclide fractions.

In order to estimate the radiation dose from the radioactive contamination levels for each secondary waste, the projected curie concentration for the nine radionuclides (plus barium-137 and yttrium-90 daughters) were entered into MicroShield, a software program used to analyze shielding and estimate exposure from gamma radiation. For the scrubber grout, ion exchange media, and activated carbon, a 55-gallon drum was used as the disposal container. The HEPA filters were grouped together in a rectangular volume with an iron/steel container. The estimated dose results were on contact at $1 \mathrm{~cm}$ from the container. The results are presented in Appendix $\mathrm{C}$ and are considered preliminary as no independent verification has been completed to date.

The mercury concentration in the various secondary wastes was calculated from the mass balance using calculations similar to those for the above radionuclides with the additional calculation for particulate and gaseous mercury whenever noted in the "Total" mass balance. In all cases, the mercury concentration was calculated in terms of milligrams of mercury per kilogram of secondary waste $(\mathrm{mg} / \mathrm{kg})$ to match the regulatory units. Appendix D shows the calculated mercury concentrations for each secondary waste.

\section{PROJECTED DISPOSAL PATHS}

Table 1 presents the resulting sum of fractions, TRU content, and mercury concentration for the various waste streams for the baseline off-gas flowsheet. Again, to meet a specific waste classification, the sum of fractions must be less than 1. Furthermore, the regulatory limit between low and high mercury is $260 \mathrm{mg} / \mathrm{kg}$. The results for each secondary waste stream are discussed in individual sections below.

Table 1. SBW Vitrification Flowsheet Secondary Waste Results.

\begin{tabular}{|c|c|c|c|c|c|c|c|c|}
\hline \multirow[b]{3}{*}{ Secondary Waste } & \multicolumn{5}{|c|}{ Sum of Fractions } & \multirow{3}{*}{$\begin{array}{l}\text { Major } \\
\text { Nuclide }\end{array}$} & \multirow{3}{*}{$\begin{array}{l}\mathrm{TRU} \\
\mathrm{nCi} / \mathrm{g}\end{array}$} & \multirow{3}{*}{$\begin{array}{c}\text { Mercury } \\
\mathrm{mg} / \mathrm{kg}\end{array}$} \\
\hline & \multicolumn{2}{|c|}{ Hanford } & \multicolumn{2}{|c|}{ NRC } & \multirow[b]{2}{*}{ Envirocare } & & & \\
\hline & Cat 1 & Cat 3 & Class A & Class C & & & & \\
\hline $\begin{array}{l}\text { Combined Scrub } \\
\text { Grout with CsIX }\end{array}$ & 216 & 0.0 & 86 & 0.0 & 144 & $\mathrm{Sr}$ & $<1$ & 3730 \\
\hline Ion Exchange Media & 74600 & 0.1 & 410 & 0.1 & 10700 & Cs & $<1$ & $<1$ \\
\hline HEPA Filter Set \#1 & 1180 & 0.0 & 24 & 0.5 & 137 & $\mathrm{Cs}, \mathrm{Sr}, \mathrm{I}$ & 2.4 & 2360 \\
\hline Activated Carbon & 0.0 & 0.0 & 0.0 & 0.0 & 0.0 & None & $<1$ & 78800 \\
\hline HEPA Filter Set \#2 & 0.0 & 0.0 & 0.0 & 0.0 & 0.0 & None & $<1$ & $<1$ \\
\hline
\end{tabular}




\subsection{Scrubber Blowdown Grout Disposal}

From a radioactivity standpoint, recycling the majority of the acid scrubber blowdown and combining a small amount with the caustic scrubber solution greatly improves the waste disposal possibilities for the scrubber grout. As shown in Table 1, the scrubber grout easily meets the Hanford Category 3 and NRC Class C lowlevel waste limits for the sum of the fractions rule. The grouted waste would not meet the waste acceptance criteria (WAC) for Envirocare, Hanford Category 1, nor NRC Class A due to the presence of strontium-90. With the cesium removed, the contact radiation dose from a 55 gallon drum is expected to be less than 1 $\mathrm{mR} / \mathrm{hr}$ (Appendix C). Therefore, the grout will be contact handled, but would be Category 3 / Class C waste due to the remaining strontium-90.

Calculations show the mercury level in the grout to be $3730 \mathrm{mg} / \mathrm{kg}$. In the combined scrub solution prior to grouting, the mercury level is over $10000 \mathrm{mg} / \mathrm{kg}$. At present, it is expected the disposal sites will only require successful completion of the TCLP for the hazardous metals (Universal Treatment Standard for mercury is $0.025 \mathrm{mg} / \mathrm{L}$ in the TCLP leachate). However, since the mercury values are well over the high mercury limit of $260 \mathrm{mg} / \mathrm{kg}$ in the waste, an amalgamation equivalency agreement may be needed with the disposal sites. The projected grout formulation uses blast furnace slag, which has been shown to retain mercury due to sulfur in the slag. Prior tests with NGLW simulants have shown that whenever blast furnace slag is used, the mercury will pass leach tests (TCLP) even at mercury levels as high as $4260 \mathrm{mg} / \mathrm{kg}$ in the simulated waste and $1910 \mathrm{mg} / \mathrm{kg}$ in the grout. ${ }^{1}$ Amalgamation is the required treatment process for high mercury; therefore, grouting may need to be demonstrated/accepted as a process with equivalent results. TCLP at the higher mercury concentrations will be needed.

\subsection{Ion Exchange Media Disposal}

There are two options for disposal of the ion exchange media. First, there is the option of placing the media in a high integrity container for disposal as remote handled material at Hanford as Category 3 material. The cesium concentration in the media is $3 \%$ of the cesium limit for Category 3 . This media would be extremely radioactive with about 400 curies of cesium per cubic meter. If this material were placed in a 55 gallon drum, the contact radiation dose would be about $200 \mathrm{rem}$ per hour $(\mathrm{R} / \mathrm{hr})$. It is noted that radionuclide leach testing is not required by the waste acceptance criteria.

The second possible method of disposal of the ion exchange media is to recycle the media to the melter. For media such as CST or Ionsiv IE-95, the aluminum and silicon based material should be readily incorporated with glass forming materials. After the sodium-bearing waste liquid is vitrified, any remaining tank waste solids may be washed from the tanks and subsequently vitrified. The ion exchange media could be added to the melter along with the tank solids. This latter disposal method would avoid the need for a separate waste stream.

There have been questions raised as to the need for ion exchange. For example, even though the cesium is removed, the remaining strontium-90 keeps the waste at Category 3 / Class $\mathrm{C}$ waste as noted in Table 1 . If the cesium were left in the waste, the waste form would be Category 3 / Class $\mathrm{C}$. The answer to this issue is whether the grouting process will be contact handled or remote handled. By removing the cesium, the radiation dose from a drum of grout is reduced from over 9000 millirem per hour $(\mathrm{mR} / \mathrm{hr})$ to less than 1 millirem per hour (Appendix C). The trade off is then the requirement to add shielding to the grouting process for remote handling of $9000 \mathrm{mR} / \mathrm{hr}$ as opposed to minimal or no shielding for contact handling. It is thought that the expense of an ion exchange system is less expensive than a remote handled, shielded grout mixing system. It is also noted that remote handled waste must be shielded for transportation and handling to 
less than $100 \mathrm{mR} / \mathrm{hr}$. Cost tradeoff studies are needed to evaluate the ion exchange options.

An alternative process may reduce the waste classification from Class $\mathrm{C}$ to Class $\mathrm{A}$ by also removing the strontium. In the baseline process, the current flowsheet uses CsIX on the acidic scrubber solution prior to combining with the caustic scrub. Cesium can be removed from an acidic solution via ion exchange, but a successful strontium ion exchange media has not been found for acidic solutions. However, both cesium and strontium can be removed from alkaline solutions by ion exchange. ${ }^{5}$ The feasibility study on the vitrification of calcine ${ }^{6}$ proposes to run the ion exchange process after the acidic and caustic scrubber solutions are combined. In this case, the ion exchange takes place in an alkaline environment, which is normal operation at most other sites. Thus, if over $99 \%$ of the strontium could be removed, as well as cesium, the waste could be contact handled and be Category 1 / Class A waste. This should be a minor change to the flowsheet and accomplish more for the same unit operation.

\subsection{HEPA Filter Disposal}

HEPA filter set \#1 follows the acidic scrubber and precedes the Noxidizer ${ }_{\mathrm{TM}}$. As noted in Table 1, these filters would be highly contaminated both by radioactive particulate and mercury. With the 4 change-outs, based on the sum of fractions rule, the filters would qualify as Category 3 / Class C waste. In the set are 4 prefilters and 8 HEPA filters. If these filters were stacked together, the unit size would be $122 \mathrm{~cm} \mathrm{X} 122 \mathrm{~cm}$ $\mathrm{X} 76 \mathrm{~cm}(4 \mathrm{ft}$ X $4 \mathrm{ft} X 2.5 \mathrm{ft})$. At the projected contamination levels, this package would be about $8 \mathrm{R} / \mathrm{hr}$ on contact and would need remote handling (Appendix C).

The estimated mercury concentration exceeds $2300 \mathrm{mg} / \mathrm{kg}$ for HEPA filter set \#1. Without further treatment, there is nothing in the filters to prevent mercury from leaching out. Without a successful TCLP test, the disposal sites will most likely reject the waste. The high levels of mercury present a significant, if not impossible, problem for direct disposal of filter set $\# 1$.

There are three possible solutions to resolve the high radiation and mercury, other than frequent, excessive change-outs. First, continue to use the INTEC filter leach system; second, washable ceramic filters could be utilized; and third, the mercury could be driven to the acidic scrubber solution.

The INTEC filter leach system is housed in the New Waste Calciner Facility (NWCF). The system can handle about 200 filters per year and generates about 300 to 400 gallons of liquid waste per filter. This waste is reduced by a factor of 30 in the Process Equipment Waste Evaporator (PEW) for a total of about 2500 gallons per year as NGLW. With the 4 complete change-outs, 48 filters would be processed through the filter leach and PEW systems and would generate 500 to 700 gallons of NGLW.

In-situ washable HEPA filters offer an option for treatment of HEPA filter set \#1. The wash water or acid could be added to the acidic scrubber solution and recycled to the melter. This would avoid another secondary waste stream. The filters would not need to be changed out. Savannah River Site (SRS) has been experimenting with washable ceramic HEPA filters ${ }^{7,8}$ and claims much lower wash solution volumes being generated. Since the SRS test filters are small, additional studies are needed to determine if such filters can handle the projected flows, the amount of rinse solution produced, and any plugging problems caused by the acidic scrubber off-gas.

The third option could resolve the mercury issue, but not the radiation levels on filter set \#1. In this case an oxidant is added to the off-gas stream prior to the acidic scrubber. The oxidant, such as hydrogen peroxide, would oxidize the gaseous mercury such that the mercury is scrubbed by the acidic solution, which keeps the 
mercury from being collected on the activated carbon. With the use of an oxidant, it is possible to drive the mercury to a different secondary waste stream. Mercury BDAT equivalency agreements, if required for high mercury, may drive the direction of mercury to the grout or activated carbon.

For the final HEPA filters, set \#2, it has been proposed to change out the prefilters every 6 months to avoid plugging problems following the caustic scrubber. The main filters in the banks would remain in the system for the entire 2 years. Appendix B shows the estimated sum of fractions for both the prefilters and the main filters. In both cases, these final filters are low-level Category 1 and Class A waste as shown in Table 1. Additionally, the radiation levels are low enough that the filters could be disposed of at Envirocare of Utah. Since HEPA set \#2 follows the activated carbon beds, the mercury levels are well below disposal limits.

In addition to the process off-gas filters, there are the facility heating, ventilation, air conditioning (HVAC) filters. The vitrification feasibility study shows 28 inlet filter banks and 17 outlet filter banks. ${ }^{9}$ The inlet filters are single banks of 16 HEPA filters and 16 prefilters. The planned outlet filters are double banks of 32 HEPA filters and 16 prefilters. This totals 448 inlet HEPAs and 448 prefilters that should be "cold" for disposal. The outlet filters will total 544 HEPAs and 272 prefilters that could be potentially "hot" filters for disposal. Thus, there are a significant number of filters to be radiologically surveyed, evaluated, and appropriately disposed of at facility closure.

\subsection{Activated Carbon Disposal}

As a result of the two scrubber operations and HEPA filtering, the activated carbon is not anticipated to present a radiological disposal problem. The carbon could be disposed of at any of the sites. However, the main issue for the activated carbon is the very high mercury level at $78800 \mathrm{mg} / \mathrm{kg}$. The current plan is to utilize sulfur impregnated granulated activated carbon, such as Mersorb supplied by Selective Adsorptions Associates. The manufacturer claims the material can absorb up to 20 weight percent (wt\%) mercury. In other words, $100 \mathrm{~kg}$ Mersorb can adsorb $20 \mathrm{~kg}$ of mercury and pass TCLP leach tests. In the current flowsheet, about $90 \%$ of the total mercury in the SBW ends up on the activated carbon. For the $54 \mathrm{~m}^{3}$ of activated carbon, the mercury loading would be about $9 \mathrm{wt} \%$.

Leach tests are needed to verify the mercury loading levels on Mersorb with the projected off-gas. The mercury that chemically reacts with the sulfur should not leach. However, it may be possible that mercury trapped in the carbon matrix could leach out. Since the loading is about half the theoretical loading, the trapped mercury may also chemically react over time. These issues will need to be investigated utilizing standard TCLP tests.

As with the grouted waste, if the activated carbon can be shown to pass the leach test (TCLP), amalgamation equivalency agreements may also be needed with the disposal site and regulators.

Due to the high mercury concentration in the secondary waste streams, it may also be possible to collect most of the mercury as elemental mercury. It is estimated that less than two 55-gallon drums would be needed (weight limits not withstanding!) if all the mercury in the SBW were collected. Utilizing the oxidant method, all the mercury could be driven into the acidic scrub solution. A mercury removal system could then be added to the acidic scrubber blowdown stream prior to recycle and grouting. Additional cleanup steps, such as triple distilling, may be needed to render the mercury free of radioactive contamination for recovery and other uses or amalgamation and disposal. 


\section{WASTE FORM TEST MATRIX}

In order to verify the waste forms meet the various disposal sites' waste acceptance criteria, considerable acceptance testing is needed. Table 2 presents a compilation of waste acceptance criteria from the Hanford Site, Nevada Test Site, and Envirocare of Utah as well as Department of Energy and Nuclear Regulatory Commission guidelines. ${ }^{10-15}$ Each disposal site's criteria are somewhat different, but the common elements persist due to the federal guidelines. On the left of Table 2 are the respective test requirements with short descriptions, and on the right are the various secondary wastes and the tests and calculations needed to meet the requirements. The list is lengthy and demonstrates the extent of testing needed to ensure the waste has a "home." Furthermore, this is a first compilation and may not contain all specific requirements. 


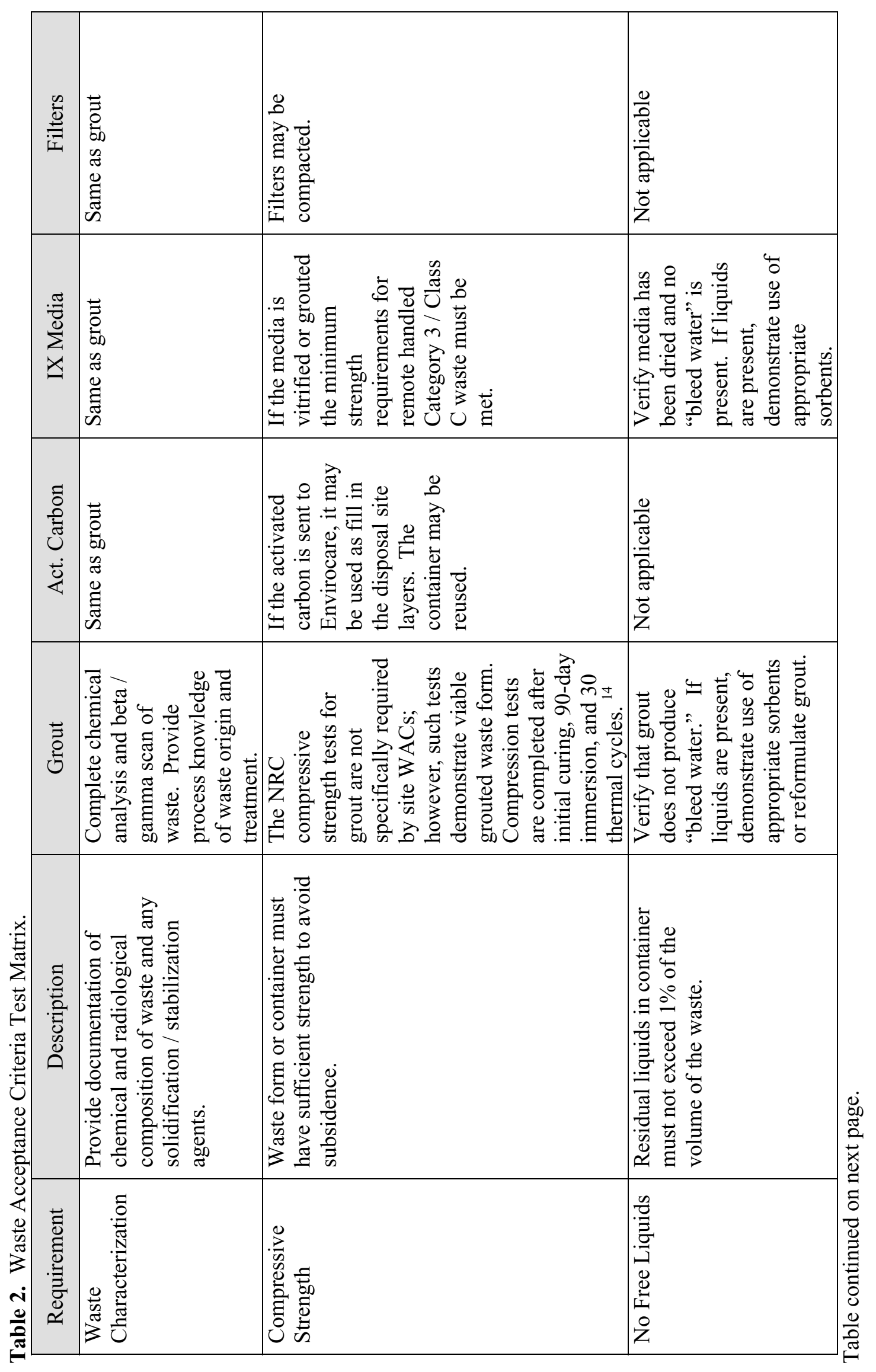




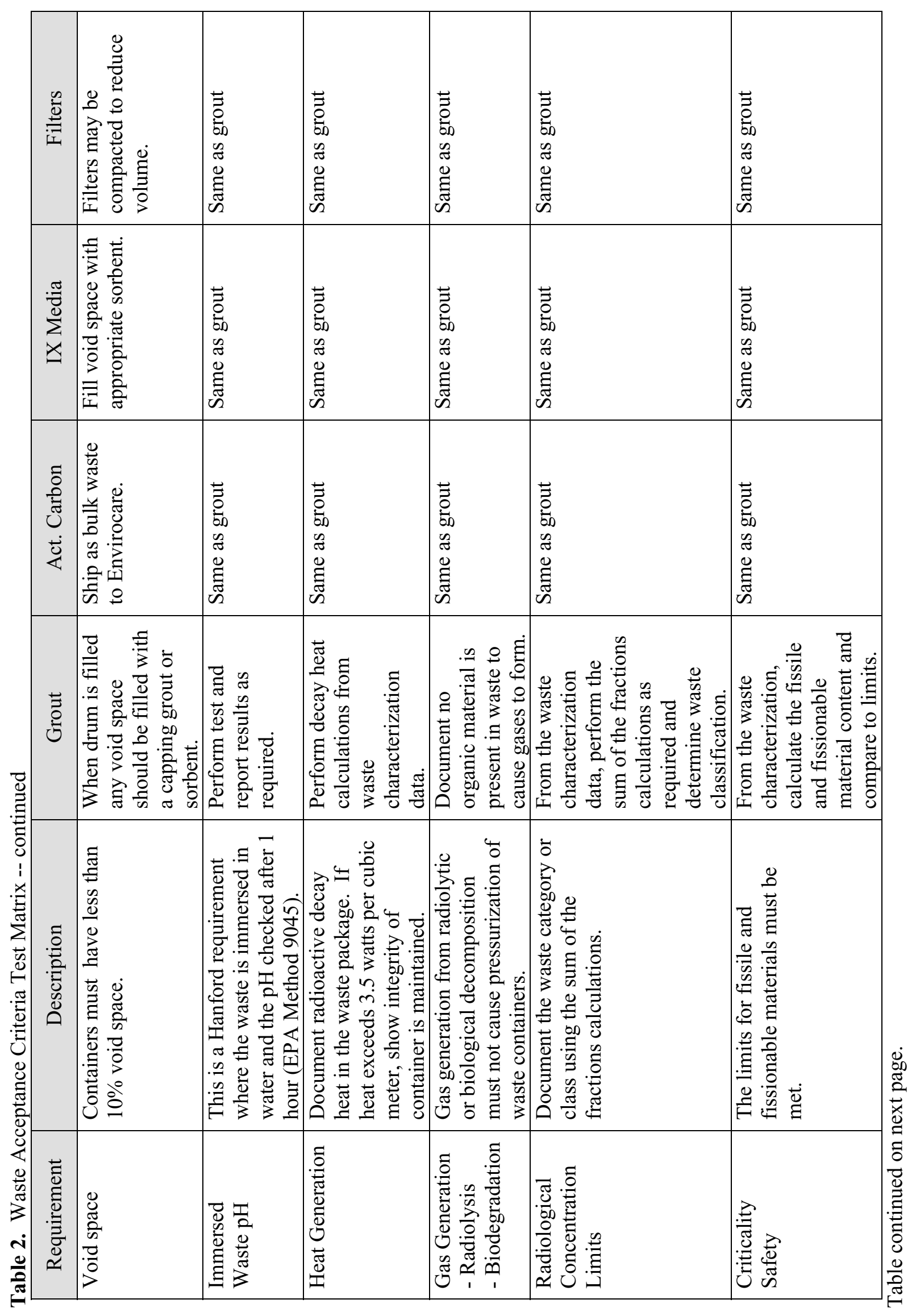




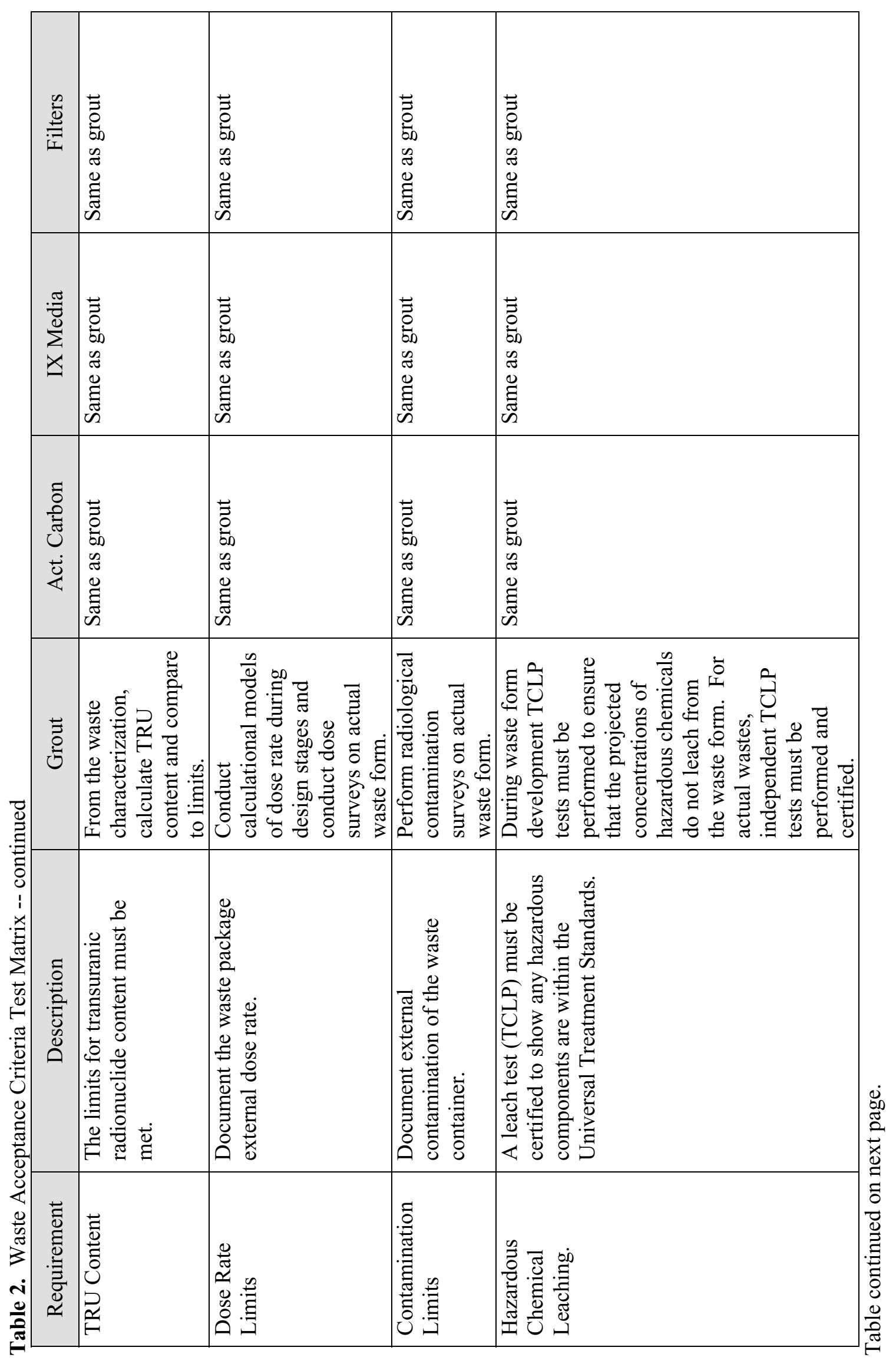




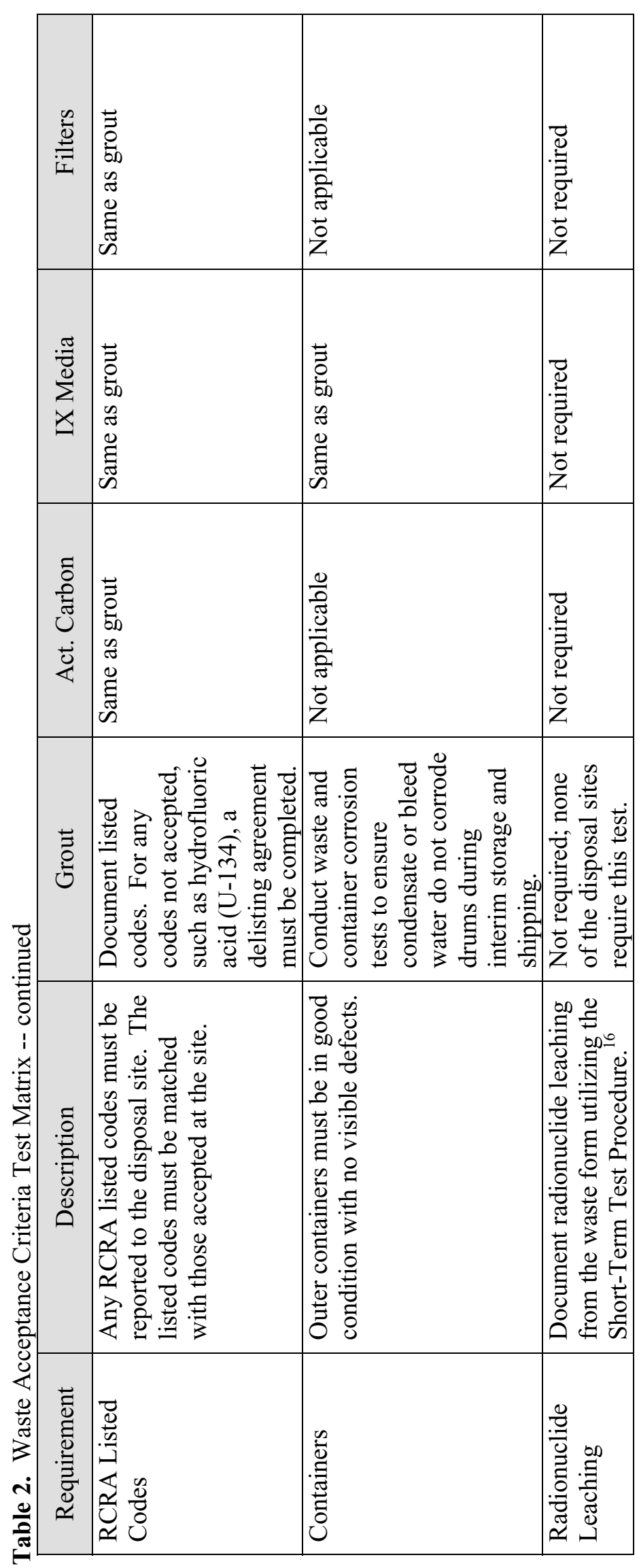




\section{RECOMMENDATIONS AND ISSUES}

\subsection{Disposal Strategy Summary}

1. The liquid scrubber blowdown solutions will be combined, grouted, and disposed of as Category 3 / Class A mixed low-level waste at Hanford or NTS.

2. The activated carbon will be packaged and disposed of as Category 1 / Class A mixed low-level waste at Envirocare of Utah, Hanford, or NTS.

3. The ion exchange media will be recycled to the melter. If this is not feasible, then ion exchange media will be disposed of in a HIC at Hanford as remote handled Category 3 mixed low-level waste.

4. Highly contaminated HEPA filters will be leached. The leachate will be combined with other NGLW for treatment and disposal. Decontaminated filters (HEPA set \#1) and other minor contaminated filters (HEPA set \#2 and HVAC) will be disposed of as Category 1 / Class A mixed low-level waste at Envirocare of Utah, Hanford, or NTS.

\subsection{Disposal Issues and Recommendations}

1. The mercury and long-lived radionuclides must be carefully followed throughout the processes and waste streams and a disposal "home" determined. All possible process flowsheets must evaluate secondary waste disposal as a major factor in process selection.

2. Washable ceramic filters are recommended for HEPA set \#1 in the off-gas system due to high radioactive particulate and mercury buildup. This would avoid several change-outs and eliminate a remote handled waste.

3. Removal of both cesium and strontium should be considered on the combined acidic and caustic scrubber solutions. Research testing is needed to determine if adequate strontium removal can be achieved. A cost tradeoff study is needed to select the use of the ion exchange or remote handled grout processing.

4. The ion exchange media should be sent to the melter; therefore, the media should be compatible with the melter glass former materials or frit. Melter testing with ion exchange media is needed.

5. Mercury leach testing is needed to verify retention by activated carbon and grout.

6. If potential disposal sites do not accept TCLP for high mercury, then mercury amalgamation equivalency must be pursued with regulators and disposal sites for both the grout and activated carbon waste streams.

7. Mercury collection and removal should be evaluated.

8. Hanford and NTS are not currently accepting off-site mixed waste for disposal. This should be resolved by the title design phase.

9. The non-acceptance of RCRA listed code (U134) for hydrofluoric acid must be resolved with disposal sites. 


\section{REFERENCES}

1. A. K. Herbst, et al., Idaho Nuclear Technology and Engineering Center Low-Activity Waste Process Technology Program FY-2000 Status Report" INEEL/EXT-2000-01167, October 2000.

2. D. D. Taylor, C. M. Barnes, L. Lauerhass, INEEL SBW Vitrification Process, INEEL/EXT-01-01139, September 2001.

3. C. M. Barnes, Systems Design, to L. Lauerhass, Environmental R\&D, CMB-13-01, November 14, 2001, "Interim SBW Vitrification Mass Balance Update".

4. 40 CFR 268.48, "Land Disposal Restrictions Universal Treatment Standards," Code of Federal Regulations, Office of the Federal Register.

5. J. E. Miller and N. E. Brown, Development and Properties of Crystalline Silicotitanate (CST) Ion Exchangers for Radioactive Waste Applications, SAND97-00771, April 1997.

6. S. O. Bates, et al., Feasibility Study for Vitrification of Calcine in the Idaho Waste Vitrification Facility, INEEL/EXT-01-0978, September 2001.

7. D. J. Adamson, Experimental Investigation of In Situ Cleanable HEPA Filter, WSRC-MS-99-00226, March 1999.

8. D. J. Adamson and T. D. Phillips, In Situ Cleanable HEPA Filter, WSRC-MS-99-00790, Nov. 1999.

9. J. J. Quigley, et al., Feasibility Study for Vitrification of Sodium-Bearing Waste, INEEL/EXT-200000952, September 2000.

10. Fluor Hanford, Hanford Site Solid Waste Acceptance Criteria, HNF-EP-0063, Revision 6, April 2001.

11. U.S. Department of Energy Nevada Operations Office, Nevada Test Site Waste Acceptance Criteria, DOE/NV-325-Rev. 3, December 2000.

12. Envirocare of Utah, Bulk Waste Acceptance Criteria, Rev. 3, May 2001.

13. Envirocare of Utah, Containerized Waste Facility Waste Acceptance Criteria, TSC-2.0 Rev. 0, October 2001.

14. U. S. Department of Energy Office of Environmental Management, Radioactive Waste Management Manual" DOE M 435.1-1, July 1999.

15. U.S. Nuclear Regulatory Commission Low-Level Waste Management Branch, Technical Position on Waste Form, Revision 1, January 1991.

16. ANSI/ANS-16.1, April, 1986, "American National Standard Measurement of the Leachability of Solidified Low-Level Radioactive Wastes by a Short-Term Test Procedure," American National Standards Institute/American Nuclear Society. 

APPENDIX A

SECONDARY WASTE CHARACTERIZATION 



\begin{tabular}{|c|c|c|c|c|c|}
\hline & $\begin{array}{l}\text { Initial SBW } \\
\text { with Solids }\end{array}$ & $\begin{array}{r}\text { Acidic } \\
\text { Scrub } \\
\text { Blowdown }\end{array}$ & $\begin{array}{r}\text { Caustic } \\
\text { Scrub } \\
\text { Blowdown }\end{array}$ & $\begin{array}{r}\text { Combined } \\
\text { Scrub }\end{array}$ & $\begin{array}{r}\text { Combined } \\
\text { Scrub } \\
\text { Grout }\end{array}$ \\
\hline Species & Molar & Molar & Molar & Molar & $\mathrm{g} / \mathrm{m}^{3}$ \\
\hline $\mathrm{Ag}+1$ & 1.56E-05 & 5.50E-06 & $1.66 \mathrm{E}-16$ & $2.79 \mathrm{E}-06$ & $1.60 \mathrm{E}-01$ \\
\hline $\mathrm{Al}+3$ & 5.61E-01 & $1.06 \mathrm{E}-06$ & 1.09E-12 & 5.37E-07 & 7.73E-03 \\
\hline As +5 & 1.66E-04 & 2.89E-05 & 8.74E-16 & 1.47E-05 & 5.86E-01 \\
\hline$B+3$ & 1.86E-02 & 5.29E-02 & $1.54 \mathrm{E}-12$ & 2.68E-02 & $1.55 \mathrm{E}+02$ \\
\hline $\mathrm{Ba}+2$ & 7.29E-05 & 1.91E-05 & 5.78E-16 & $9.71 \mathrm{E}-06$ & 7.12E-01 \\
\hline $\mathrm{Ca}+2$ & 5.15E-02 & 4.67E-02 & $1.41 \mathrm{E}-12$ & 2.37E-02 & $5.06 \mathrm{E}+02$ \\
\hline $\mathrm{Cd}+2$ & 4.54E-03 & $3.42 \mathrm{E}-03$ & $1.03 E-13$ & $1.74 \mathrm{E}-03$ & $1.04 \mathrm{E}+02$ \\
\hline $\mathrm{Cl}-1$ & 2.41E-02 & 1.39E-01 & 1.18E-01 & 1.14E-01 & $2.17 \mathrm{E}+03$ \\
\hline CO3-2 & $0.00 E+00$ & $0.00 E+00$ & $2.23 E+00$ & 8.27E-01 & $2.65 E+04$ \\
\hline $\mathrm{Cr}+3$ & 4.64E-03 & $5.44 \mathrm{E}-08$ & $5.60 \mathrm{E}-14$ & 2.76E-08 & 7.65E-04 \\
\hline $\mathrm{Cs}+1$ & 2.23E-05 & $9.46 \mathrm{E}-05$ & 2.81E-15 & $4.80 \mathrm{E}-08$ & $3.40 \mathrm{E}-03$ \\
\hline $\mathrm{Cu}+2$ & 7.85E-04 & 1.37E-04 & 4.13E-15 & 6.93E-05 & $2.35 E+00$ \\
\hline $\mathrm{F}-1$ & 8.17E-02 & $2.95 \mathrm{E}-01$ & 2.44E-01 & $2.41 \mathrm{E}-01$ & $2.44 \mathrm{E}+03$ \\
\hline $\mathrm{Fe}+3$ & $2.24 \mathrm{E}-02$ & $3.29 E-04$ & 9.94E-15 & 1.67E-04 & $4.97 \mathrm{E}+00$ \\
\hline $\mathrm{Gd}+3$ & 7.05E-05 & $1.33 E-10$ & 1.37E-16 & $6.74 \mathrm{E}-11$ & 5.66E-06 \\
\hline $\mathrm{H}+1$ & $2.40 \mathrm{E}+00$ & 9.59E-01 & $0.00 \mathrm{E}+00$ & $0.00 E+00$ & $0.00 \mathrm{E}+00$ \\
\hline $\mathrm{Hg}+2$ & $3.76 \mathrm{E}-03$ & 1.33E-01 & $3.45 \mathrm{E}-12$ & 6.76E-02 & $7.24 \mathrm{E}+03$ \\
\hline$K+1$ & $1.65 \mathrm{E}-01$ & $4.02 E-01$ & $1.20 \mathrm{E}-11$ & 2.04E-01 & $4.26 \mathrm{E}+03$ \\
\hline $\mathrm{Li}+1$ & 3.80E-04 & 1.75E-04 & $5.28 \mathrm{E}-15$ & 8.87E-05 & $3.29 \mathrm{E}-01$ \\
\hline$M g+2$ & 8.83E-03 & $1.54 \mathrm{E}-03$ & $4.65 \mathrm{E}-14$ & 7.80E-04 & $1.01 \mathrm{E}+01$ \\
\hline$M n+4$ & $1.51 \mathrm{E}-02$ & 7.31E-04 & $2.21 \mathrm{E}-14$ & $3.70 \mathrm{E}-04$ & $1.09 E+01$ \\
\hline $\mathrm{Mo}+6$ & $2.52 E-04$ & $3.03 E-10$ & $3.12 \mathrm{E}-16$ & $1.54 \mathrm{E}-10$ & 7.87E-06 \\
\hline $\mathrm{Na}+1$ & $1.52 E+00$ & $1.32 E+00$ & $7.98 \mathrm{E}+00$ & $4.12 E+00$ & $5.06 \mathrm{E}+04$ \\
\hline $\mathrm{Ni}+2$ & $3.25 \mathrm{E}-03$ & 5.67E-04 & $1.71 \mathrm{E}-14$ & 2.87E-04 & $9.00 \mathrm{E}+00$ \\
\hline NO3-1 & $5.94 \mathrm{E}+00$ & 8.67E-01 & 2.78E-01 & 5.43E-01 & $1.80 E+04$ \\
\hline $\mathrm{OH}-1$ & $0.00 E+00$ & $0.00 E+00$ & 1.29E-01 & 4.79E-02 & $4.35 \mathrm{E}+02$ \\
\hline $\mathrm{Pb}+2$ & 2.89E-03 & $1.02 \mathrm{E}-03$ & 3.07E-14 & 5.15E-04 & $5.70 \mathrm{E}+01$ \\
\hline $\mathrm{Pd}+3$ & $2.52 \mathrm{E}-05$ & $4.75 \mathrm{E}-11$ & $4.89 \mathrm{E}-17$ & $2.41 \mathrm{E}-11$ & 1.37E-06 \\
\hline PO4-3 & 1.11E-02 & 1.46E-02 & 4.40E-13 & 7.41E-03 & $3.76 \mathrm{E}+02$ \\
\hline $\mathrm{Ru}+4$ & 5.88E-05 & 1.57E-09 & $1.61 \mathrm{E}-15$ & $7.95 \mathrm{E}-10$ & 4.29E-05 \\
\hline $\mathrm{Se}+4$ & 7.97E-05 & 1.65E-09 & $1.70 \mathrm{E}-15$ & 8.39E-10 & $3.54 \mathrm{E}-05$ \\
\hline $\mathrm{Si}+4$ & 3.77E-03 & 7.11E-09 & $7.32 \mathrm{E}-15$ & $3.60 \mathrm{E}-09$ & 5.40 E-05 \\
\hline $\mathrm{Sr}+2$ & 4.78E-05 & 1.94E-05 & 5.86E-16 & 9.84E-06 & 4.60E-01 \\
\hline SO4-2 & 5.09E-02 & $1.22 \mathrm{E}-01$ & $1.38 \mathrm{E}+00$ & $5.74 \mathrm{E}-01$ & $2.94 E+04$ \\
\hline$V+5$ & $3.44 \mathrm{E}-04$ & $6.49 \mathrm{E}-10$ & $6.68 \mathrm{E}-16$ & $3.29 \mathrm{E}-10$ & 8.95E-06 \\
\hline$Z n+2$ & 1.40E-03 & 7.29E-05 & 2.20E-15 & 3.69E-05 & $1.29 E+00$ \\
\hline $\mathrm{Zr}+4$ & 1.24E-02 & 2.34E-08 & $2.41 \mathrm{E}-14$ & 1.19E-08 & 5.78E-04 \\
\hline $\mathrm{H} 2 \mathrm{O}$ & $4.61 \mathrm{E}+01$ & $5.43 E+01$ & $5.55 \mathrm{E}+01$ & $5.54 \mathrm{E}+01$ & $0.00 \mathrm{E}+00$ \\
\hline TOC, g/liter & $3.70 \mathrm{E}-01$ & $0.00 E+00$ & $0.00 E+00$ & $0.00 E+00$ & $0.00 E+00$ \\
\hline UDS, g/liter & $2.73 E+00$ & $0.00 \mathrm{E}+00$ & $0.00 \mathrm{E}+00$ & $0.00 \mathrm{E}+00$ & $0.00 \mathrm{E}+00$ \\
\hline Slag & & & & & $1.05 E+06$ \\
\hline Cement & & & & & $1.17 \mathrm{E}+05$ \\
\hline
\end{tabular}




\begin{tabular}{|c|c|c|c|c|c|}
\hline & $\begin{array}{l}\text { Initial SBW } \\
\text { with Solids }\end{array}$ & $\begin{array}{r}\text { Acidic } \\
\text { Scrub } \\
\text { Blowdown }\end{array}$ & $\begin{array}{r}\text { Caustic } \\
\text { Scrub } \\
\text { Blowdown }\end{array}$ & $\begin{array}{r}\text { Combined } \\
\text { Scrub }\end{array}$ & $\begin{array}{r}\text { Combined } \\
\text { Scrub } \\
\text { Grout }\end{array}$ \\
\hline Nuclide & $\mathrm{Ci} / \mathrm{L}$ & $\mathrm{Ci} / \mathrm{L}$ & $\mathrm{Ci} / \mathrm{L}$ & $\mathrm{Ci} / \mathrm{L}$ & $\mathrm{Ci} / \mathrm{m}^{3}$ \\
\hline $\mathrm{Pa}-233$ & $2.86 \mathrm{E}-06$ & $5.40 \mathrm{E}-12$ & $5.56 \mathrm{E}-18$ & $2.74 \mathrm{E}-12$ & 1.46E-09 \\
\hline U-232 & 6.25E-09 & $1.18 \mathrm{E}-14$ & $1.22 \mathrm{E}-20$ & $5.98 \mathrm{E}-15$ & $3.19 \mathrm{E}-12$ \\
\hline U-233 & 8.16E-10 & $1.54 \mathrm{E}-15$ & 1.59E-21 & $7.80 \mathrm{E}-16$ & 4.17E-13 \\
\hline U-234 & 1.11E-06 & $2.10 \mathrm{E}-12$ & $2.16 \mathrm{E}-18$ & $1.06 \mathrm{E}-12$ & $5.67 \mathrm{E}-10$ \\
\hline U-235 & 2.91E-08 & 5.49E-14 & 5.65E-20 & $2.78 \mathrm{E}-14$ & $1.49 \mathrm{E}-11$ \\
\hline U-236 & 4.61E-08 & 8.70E-14 & 8.96E-20 & $4.41 \mathrm{E}-14$ & $2.36 \mathrm{E}-11$ \\
\hline U-238 & 3.24E-08 & $6.11 \mathrm{E}-14$ & $6.29 \mathrm{E}-20$ & $3.09 \mathrm{E}-14$ & $1.65 \mathrm{E}-11$ \\
\hline $\mathrm{Np}-237$ & 2.01E-06 & 3.80E-12 & $3.91 \mathrm{E}-18$ & $1.92 \mathrm{E}-12$ & 1.03E-09 \\
\hline Np-239 & 2.07E-08 & $3.90 \mathrm{E}-14$ & 4.02E-20 & $1.98 \mathrm{E}-14$ & $1.06 \mathrm{E}-11$ \\
\hline Pu-238 & 8.08E-04 & 1.53E-09 & $1.57 \mathrm{E}-15$ & 7.73E-10 & 4.13E-07 \\
\hline Pu-239 & 1.15E-04 & $2.17 \mathrm{E}-10$ & $2.24 \mathrm{E}-16$ & $1.10 \mathrm{E}-10$ & $5.88 \mathrm{E}-08$ \\
\hline Pu-240 & 9.86E-06 & $1.86 \mathrm{E}-11$ & $1.92 \mathrm{E}-17$ & $9.43 E-12$ & 5.04E-09 \\
\hline Pu-241 & 1.87E-04 & $3.52 \mathrm{E}-10$ & 3.63E-16 & $1.78 \mathrm{E}-10$ & $9.53 \mathrm{E}-08$ \\
\hline Pu-242 & 1.72E-08 & $3.25 \mathrm{E}-14$ & $3.34 \mathrm{E}-20$ & $1.65 \mathrm{E}-14$ & $8.79 \mathrm{E}-12$ \\
\hline Am-241 & 8.93E-05 & $1.68 \mathrm{E}-10$ & $1.73 \mathrm{E}-16$ & 8.54E-11 & 4.56E-08 \\
\hline Am-243 & 2.07E-08 & $3.90 \mathrm{E}-14$ & 4.02E-20 & $1.98 \mathrm{E}-14$ & $1.06 \mathrm{E}-11$ \\
\hline $\mathrm{Cm}-242$ & 1.19E-08 & $2.25 \mathrm{E}-14$ & 2.32E-20 & $1.14 \mathrm{E}-14$ & 6.09E-12 \\
\hline $\mathrm{Cm}-243$ & 2.07E-08 & $3.90 \mathrm{E}-14$ & 4.02E-20 & $1.98 \mathrm{E}-14$ & $1.06 \mathrm{E}-11$ \\
\hline $\mathrm{Cm}-244$ & 1.67E-06 & $3.16 \mathrm{E}-12$ & $3.25 \mathrm{E}-18$ & $1.60 \mathrm{E}-12$ & $8.55 \mathrm{E}-10$ \\
\hline $\mathrm{H}-3$ & 1.02E-05 & 3.38E-06 & 1.70E-03 & 6.33E-04 & 3.38E-01 \\
\hline C-14 & 1.15E-06 & 1.55E-04 & $3.06 \mathrm{E}-15$ & 7.86E-05 & $4.20 \mathrm{E}-02$ \\
\hline Se-79 & 4.29E-07 & 8.91E-12 & $9.17 \mathrm{E}-18$ & $4.52 \mathrm{E}-12$ & 2.41E-09 \\
\hline Sr-90 & 3.14E-02 & $1.27 \mathrm{E}-02$ & $3.85 \mathrm{E}-13$ & $6.46 \mathrm{E}-03$ & $3.45 \mathrm{E}+00$ \\
\hline Y-90 & 3.14E-02 & 1.27E-02 & $3.85 \mathrm{E}-13$ & 6.46E-03 & $3.45 E+00$ \\
\hline Zr-93 & $2.15 \mathrm{E}-06$ & $4.05 \mathrm{E}-12$ & 4.17E-18 & $2.05 \mathrm{E}-12$ & 1.10E-09 \\
\hline $\mathrm{Nb}-93 \mathrm{~m}$ & 1.83E-06 & $3.45 \mathrm{E}-12$ & $3.55 \mathrm{E}-18$ & $1.75 \mathrm{E}-12$ & $9.34 \mathrm{E}-10$ \\
\hline $\mathrm{Nb}-94$ & 1.11E-06 & $2.10 \mathrm{E}-12$ & $2.16 \mathrm{E}-18$ & $1.06 \mathrm{E}-12$ & $5.68 \mathrm{E}-10$ \\
\hline Tc-99 & 1.25E-05 & $9.98 \mathrm{E}-10$ & $1.03 E-15$ & $5.06 \mathrm{E}-10$ & $2.70 \mathrm{E}-07$ \\
\hline Ru-106 & $9.74 \mathrm{E}-11$ & 2.60E-15 & 2.68E-21 & $1.32 \mathrm{E}-15$ & $7.04 \mathrm{E}-13$ \\
\hline Rh-106 & $9.74 \mathrm{E}-11$ & $1.84 \mathrm{E}-16$ & 1.89E-22 & $9.32 \mathrm{E}-17$ & $4.97 \mathrm{E}-14$ \\
\hline Cd-113m & $1.75 \mathrm{E}-06$ & 2.27E-07 & 2.87E-15 & 1.15E-07 & $6.14 \mathrm{E}-05$ \\
\hline Sn-121m & 5.48E-08 & $1.04 \mathrm{E}-13$ & 1.07E-19 & $5.25 \mathrm{E}-14$ & $2.80 \mathrm{E}-11$ \\
\hline Sn-126 & 4.05E-07 & $7.65 \mathrm{E}-13$ & 7.88E-19 & $3.88 \mathrm{E}-13$ & $2.07 \mathrm{E}-10$ \\
\hline Sb-125 & 9.02E-07 & 1.70E-12 & $1.75 \mathrm{E}-18$ & 8.63E-13 & $4.61 \mathrm{E}-10$ \\
\hline $\mathrm{Sb}-126 \mathrm{~m}$ & 4.05E-07 & $7.65 \mathrm{E}-13$ & 7.88E-19 & $3.88 \mathrm{E}-13$ & $2.07 \mathrm{E}-10$ \\
\hline Sb-126 & 5.64E-08 & $1.07 \mathrm{E}-13$ & 1.10E-19 & $5.40 \mathrm{E}-14$ & $2.88 \mathrm{E}-11$ \\
\hline Te-125m & 1.19E-07 & $2.48 \mathrm{E}-12$ & $2.55 \mathrm{E}-18$ & $1.25 \mathrm{E}-12$ & $6.70 \mathrm{E}-10$ \\
\hline $\mathrm{I}-129$ & 5.52E-08 & 2.33E-06 & 1.62E-09 & $1.18 \mathrm{E}-06$ & 6.30E-04 \\
\hline Cs-134 & $4.05 \mathrm{E}-07$ & 1.72E-06 & 5.10E-17 & $8.72 \mathrm{E}-11$ & $4.65 E-08$ \\
\hline Cs-135 & 8.74E-07 & 3.72E-06 & 1.10E-16 & $1.88 \mathrm{E}-10$ & $1.01 \mathrm{E}-07$ \\
\hline Cs-137 & 3.81E-02 & 1.62E-01 & $4.80 \mathrm{E}-12$ & 8.21E-06 & 4.38E-03 \\
\hline $\mathrm{Ba}-137 \mathrm{~m}$ & 3.49E-02 & 1.48E-01 & 4.40E-12 & 7.51E-06 & 4.01E-03 \\
\hline Ce-144 & $4.50 \mathrm{E}-12$ & 8.50E-18 & 8.75E-24 & $4.31 \mathrm{E}-18$ & $2.30 \mathrm{E}-15$ \\
\hline Pr-144 & $4.50 \mathrm{E}-12$ & 8.50E-18 & 8.75E-24 & $4.31 \mathrm{E}-18$ & $2.30 \mathrm{E}-15$ \\
\hline Pm-146 & 9.54E-09 & $1.80 \mathrm{E}-14$ & $1.85 \mathrm{E}-20$ & $9.12 \mathrm{E}-15$ & $4.87 \mathrm{E}-12$ \\
\hline Pm-147 & $5.40 \mathrm{E}-06$ & $1.02 \mathrm{E}-11$ & $1.05 \mathrm{E}-17$ & 5.17E-12 & 2.76E-09 \\
\hline Sm-151 & $3.02 \mathrm{E}-04$ & $5.70 \mathrm{E}-10$ & 5.87E-16 & $2.89 \mathrm{E}-10$ & $1.54 \mathrm{E}-07$ \\
\hline Eu-152 & 1.27E-06 & $2.40 \mathrm{E}-12$ & 2.47E-18 & $1.22 \mathrm{E}-12$ & $6.49 \mathrm{E}-10$ \\
\hline Eu-154 & 6.16E-05 & 1.16E-10 & $1.20 \mathrm{E}-16$ & 5.89E-11 & $3.15 \mathrm{E}-08$ \\
\hline Eu-155 & 1.58E-05 & $2.98 \mathrm{E}-11$ & 3.06E-17 & $1.51 \mathrm{E}-11$ & 8.06E-09 \\
\hline Co-60 & 7.05E-06 & 1.23E-06 & $3.71 \mathrm{E}-17$ & $6.23 \mathrm{E}-07$ & 3.32E-04 \\
\hline $\mathrm{Ni}-63$ & 4.06E-05 & 7.09E-06 & 2.14E-16 & 3.59E-06 & 1.92E-03 \\
\hline
\end{tabular}




\begin{tabular}{|c|c|c|c|c|c|c|}
\hline Nuclide & $\begin{array}{r}\text { CsIX } \\
\text { Media } \\
2 \text { years } \\
\mathrm{Ci} / \mathrm{m}^{3} \\
\end{array}$ & $\begin{array}{r}\text { HEPA } \\
\text { Set \#1 } \\
6 \text { months } \\
\mathrm{Ci} / \mathrm{m}^{3} \\
\end{array}$ & $\begin{array}{r}\text { Activated } \\
\text { Carbon } \\
2 \text { years } \\
\mathrm{Ci} / \mathrm{m}^{3} \\
\end{array}$ & $\begin{array}{r}\text { HEPA \#2 } \\
\text { Prefilters } \\
6 \text { months } \\
\mathrm{Ci} / \mathrm{m}^{3} \\
\end{array}$ & $\begin{array}{r}\text { HEPA \#2 } \\
\text { Final } \\
2 \text { years } \\
\mathrm{Ci} / \mathrm{m}^{3} \\
\end{array}$ & $\begin{array}{r}\text { Stack } \\
\text { Effluent } \\
\mathrm{Ci} / \mathrm{m}^{3} \\
\end{array}$ \\
\hline Pa-233 & & 6.63E-06 & $4.15 \mathrm{E}-18$ & $2.41 \mathrm{E}-16$ & $2.47 \mathrm{E}-18$ & $2.74 \mathrm{E}-32$ \\
\hline U-232 & & 1.45E-08 & 9.07E-21 & $5.27 \mathrm{E}-19$ & $5.40 \mathrm{E}-21$ & $5.99 \mathrm{E}-35$ \\
\hline U-233 & & 1.89E-09 & 1.18E-21 & 6.87E-20 & 7.05E-22 & $7.82 E-36$ \\
\hline U-234 & & 2.57E-06 & $1.61 \mathrm{E}-18$ & $9.36 \mathrm{E}-17$ & $9.60 \mathrm{E}-19$ & 1.07E-32 \\
\hline U-235 & & $6.74 \mathrm{E}-08$ & $4.22 \mathrm{E}-20$ & $2.45 \mathrm{E}-18$ & $2.51 \mathrm{E}-20$ & $2.79 \mathrm{E}-34$ \\
\hline U-236 & & 1.07E-07 & 6.69E-20 & $3.88 \mathrm{E}-18$ & $3.98 \mathrm{E}-20$ & 4.42E-34 \\
\hline U-238 & & 7.50E-08 & 4.69E-20 & $2.73 \mathrm{E}-18$ & 2.80E-20 & $3.10 \mathrm{E}-34$ \\
\hline $\mathrm{Np}-237$ & & 4.66E-06 & 2.92E-18 & $1.69 \mathrm{E}-16$ & $1.74 \mathrm{E}-18$ & $1.93 E-32$ \\
\hline $\mathrm{Np}-239$ & & 4.79E-08 & 3.00E-20 & $1.74 \mathrm{E}-18$ & 1.79E-20 & $1.98 E-34$ \\
\hline Pu-238 & & 1.87E-03 & 1.17E-15 & $6.81 \mathrm{E}-14$ & $6.99 \mathrm{E}-16$ & 7.75E-30 \\
\hline Pu-239 & & 2.67E-04 & 1.67E-16 & $9.70 \mathrm{E}-15$ & $9.95 \mathrm{E}-17$ & $1.10 \mathrm{E}-30$ \\
\hline Pu-240 & & $2.29 \mathrm{E}-05$ & $1.43 \mathrm{E}-17$ & 8.31E-16 & $8.52 \mathrm{E}-18$ & $9.45 \mathrm{E}-32$ \\
\hline Pu-241 & & 4.32E-04 & $2.70 \mathrm{E}-16$ & $1.57 \mathrm{E}-14$ & $1.61 \mathrm{E}-16$ & $1.79 E-30$ \\
\hline Pu-242 & & 3.99E-08 & 2.49E-20 & 1.45E-18 & $1.49 \mathrm{E}-20$ & 1.65E-34 \\
\hline Am-241 & & 2.07E-04 & $1.29 \mathrm{E}-16$ & $7.52 \mathrm{E}-15$ & $7.71 \mathrm{E}-17$ & 8.56E-31 \\
\hline Am-243 & & 4.79E-08 & 3.00E-20 & $1.74 \mathrm{E}-18$ & 1.79E-20 & $1.98 \mathrm{E}-34$ \\
\hline $\mathrm{Cm}-242$ & & $2.76 \mathrm{E}-08$ & 1.73E-20 & $1.00 \mathrm{E}-18$ & $1.03 E-20$ & $1.14 \mathrm{E}-34$ \\
\hline $\mathrm{Cm}-243$ & & 4.79E-08 & 3.00E-20 & $1.74 \mathrm{E}-18$ & 1.79E-20 & $1.98 E-34$ \\
\hline Cm-244 & & 3.88E-06 & $2.43 E-18$ & $1.41 \mathrm{E}-16$ & $1.45 \mathrm{E}-18$ & 1.61E-32 \\
\hline $\mathrm{H}-3$ & & $0.00 E+00$ & 1.27E-02 & $0.00 E+00$ & $0.00 E+00$ & $2.12 \mathrm{E}-08$ \\
\hline C-14 & & $6.02 E-03$ & $2.28 \mathrm{E}-15$ & $1.33 \mathrm{E}-13$ & 1.36E-15 & $1.51 \mathrm{E}-29$ \\
\hline Se-79 & & 1.09E-05 & 6.84E-18 & $3.98 \mathrm{E}-16$ & $4.08 \mathrm{E}-18$ & 4.53E-32 \\
\hline Sr-90 & & 4.95E-01 & $2.87 \mathrm{E}-13$ & 1.67E-11 & $1.71 \mathrm{E}-13$ & $1.90 \mathrm{E}-27$ \\
\hline Y-90 & & 4.95E-01 & 2.87E-13 & 1.67E-11 & $1.71 \mathrm{E}-13$ & $1.90 \mathrm{E}-27$ \\
\hline Zr-93 & & 4.97E-06 & 3.11E-18 & $1.81 \mathrm{E}-16$ & $1.85 \mathrm{E}-18$ & 2.06E-32 \\
\hline $\mathrm{Nb}-93 \mathrm{~m}$ & & 4.24E-06 & $2.65 \mathrm{E}-18$ & $1.54 \mathrm{E}-16$ & $1.58 \mathrm{E}-18$ & $1.75 E-32$ \\
\hline $\mathrm{Nb}-94$ & & $2.58 \mathrm{E}-06$ & 1.61E-18 & $9.37 \mathrm{E}-17$ & $9.61 \mathrm{E}-19$ & 1.07E-32 \\
\hline Tc-99 & & 1.23E-03 & 7.67E-16 & 4.46E-14 & 4.57E-16 & 5.07E-30 \\
\hline Ru-106 & & 3.19E-09 & $2.00 \mathrm{E}-21$ & 1.16E-19 & 1.19E-21 & $1.32 \mathrm{E}-35$ \\
\hline Rh-106 & & 2.26E-10 & 1.41E-22 & $8.20 \mathrm{E}-21$ & $8.42 \mathrm{E}-23$ & 9.34E-37 \\
\hline Cd-113m & & $3.62 \mathrm{E}-03$ & $2.14 \mathrm{E}-15$ & $1.25 \mathrm{E}-13$ & $1.28 \mathrm{E}-15$ & 1.42E-29 \\
\hline Sn-121m & & 1.27E-07 & 7.95E-20 & $4.62 \mathrm{E}-18$ & 4.74E-20 & $5.26 \mathrm{E}-34$ \\
\hline Sn-126 & & 9.39E-07 & 5.88E-19 & $3.41 \mathrm{E}-17$ & $3.50 \mathrm{E}-19$ & $3.89 E-33$ \\
\hline Sb-125 & & 2.09E-06 & $1.31 \mathrm{E}-18$ & $7.60 \mathrm{E}-17$ & $7.80 \mathrm{E}-19$ & 8.65E-33 \\
\hline $\mathrm{Sb}-126 \mathrm{~m}$ & & 9.39E-07 & 5.88E-19 & $3.41 \mathrm{E}-17$ & $3.50 \mathrm{E}-19$ & $3.89 E-33$ \\
\hline Sb-126 & & 1.31E-07 & 8.18E-20 & $4.75 \mathrm{E}-18$ & 4.88E-20 & 5.41E-34 \\
\hline Te-125m & & 3.04E-06 & $1.90 \mathrm{E}-18$ & $1.10 \mathrm{E}-16$ & $1.13 \mathrm{E}-18$ & $1.26 \mathrm{E}-32$ \\
\hline |-129 & & 3.71E-02 & 2.39E-09 & 1.40E-09 & $1.44 \mathrm{E}-11$ & $1.01 \mathrm{E}-20$ \\
\hline Cs-134 & 4.36E-03 & 6.68E-05 & 3.81E-17 & $2.21 \mathrm{E}-15$ & $2.27 \mathrm{E}-17$ & $2.52 \mathrm{E}-31$ \\
\hline Cs-135 & $9.42 \mathrm{E}-03$ & 1.44E-04 & $8.22 \mathrm{E}-17$ & $4.78 \mathrm{E}-15$ & $4.90 \mathrm{E}-17$ & 5.44E-31 \\
\hline Cs-137 & 4.10E+02 & $6.28 E+00$ & $3.58 \mathrm{E}-12$ & $2.08 \mathrm{E}-10$ & $2.14 \mathrm{E}-12$ & 2.37E-26 \\
\hline Ba-137m & $3.76 \mathrm{E}+02$ & $5.75 E+00$ & $3.28 \mathrm{E}-12$ & $1.91 \mathrm{E}-10$ & 1.96E-12 & 2.17E-26 \\
\hline Ce-144 & & 1.04E-11 & $6.53 \mathrm{E}-24$ & $3.79 \mathrm{E}-22$ & $3.89 E-24$ & $4.32 E-38$ \\
\hline Pr-144 & & $1.04 \mathrm{E}-11$ & $6.53 \mathrm{E}-24$ & $3.79 \mathrm{E}-22$ & 3.89E-24 & $4.32 \mathrm{E}-38$ \\
\hline $\mathrm{Pm}-146$ & & $2.21 \mathrm{E}-08$ & $1.38 \mathrm{E}-20$ & 8.03E-19 & 8.24E-21 & $9.14 \mathrm{E}-35$ \\
\hline Pm-147 & & $1.25 \mathrm{E}-05$ & 7.83E-18 & 4.55E-16 & 4.67E-18 & 5.18E-32 \\
\hline Sm-151 & & 7.00E-04 & 4.38E-16 & $2.54 \mathrm{E}-14$ & 2.61E-16 & $2.90 \mathrm{E}-30$ \\
\hline Eu-152 & & $2.95 \mathrm{E}-06$ & $1.84 \mathrm{E}-18$ & 1.07E-16 & $1.10 \mathrm{E}-18$ & $1.22 \mathrm{E}-32$ \\
\hline Eu-154 & & 1.43E-04 & 8.93E-17 & $5.19 \mathrm{E}-15$ & 5.32E-17 & 5.90E-31 \\
\hline Eu-155 & & 3.66E-05 & $2.29 \mathrm{E}-17$ & $1.33 \mathrm{E}-15$ & $1.36 \mathrm{E}-17$ & $1.51 \mathrm{E}-31$ \\
\hline Co-60 & & 4.77E-05 & $2.77 \mathrm{E}-17$ & $1.61 \mathrm{E}-15$ & $1.65 \mathrm{E}-17$ & $1.83 \mathrm{E}-31$ \\
\hline $\mathrm{Ni}-63$ & & 2.75E-04 & $1.60 \mathrm{E}-16$ & $9.28 \mathrm{E}-15$ & $9.52 \mathrm{E}-17$ & $1.06 \mathrm{E}-30$ \\
\hline
\end{tabular}



APPENDIX B

WASTE ACCEPTANCE CRITERIA SUMMARIES 



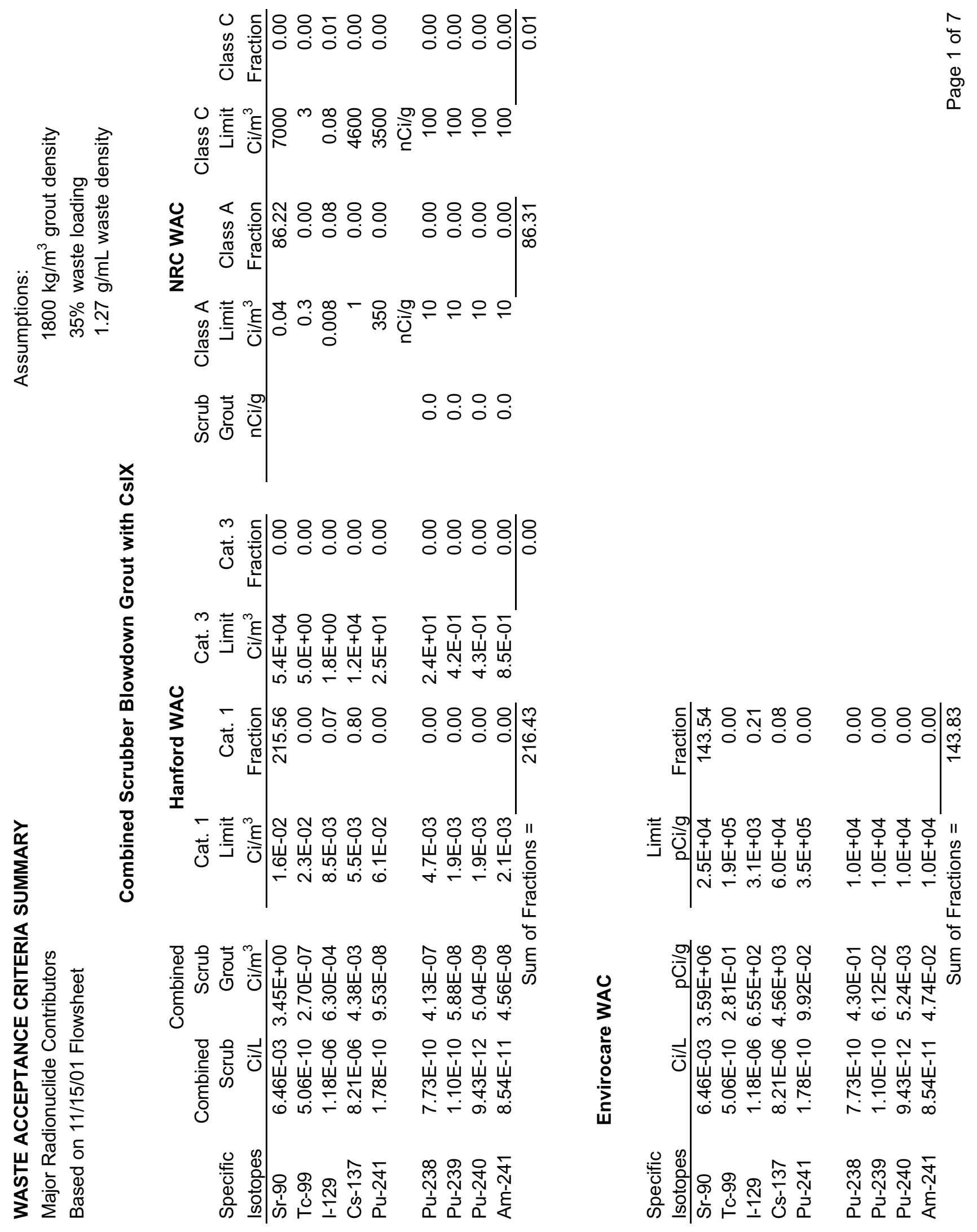



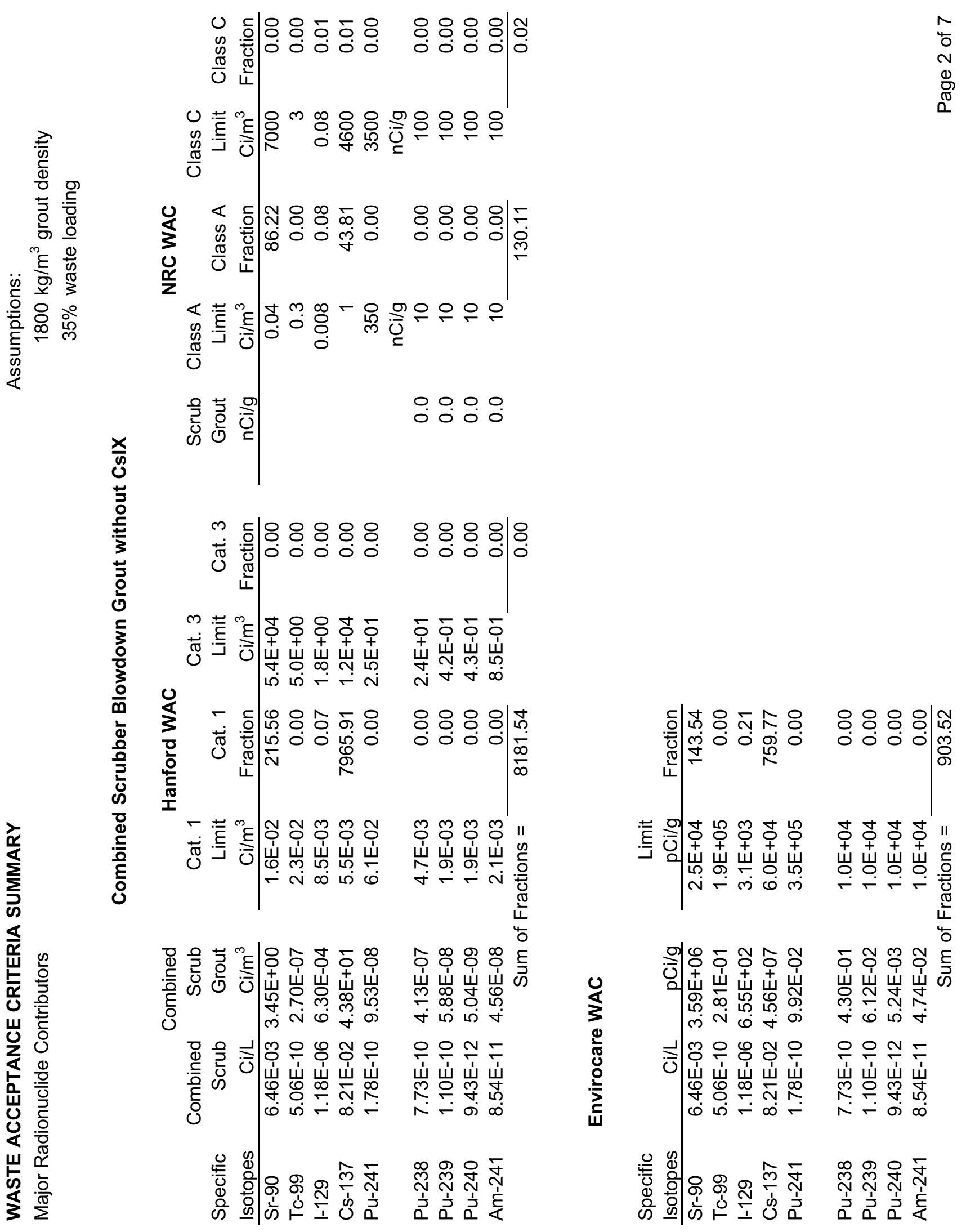


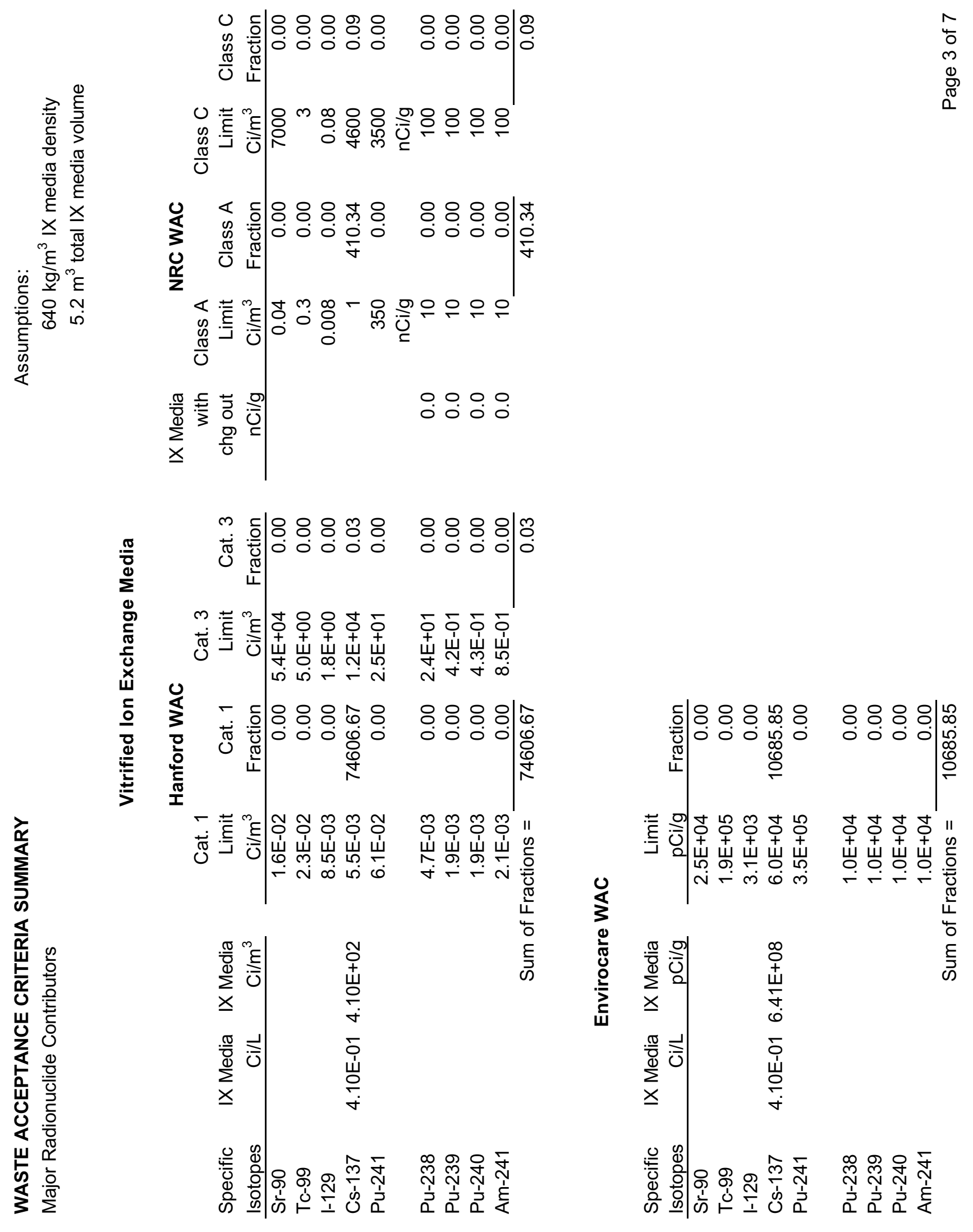



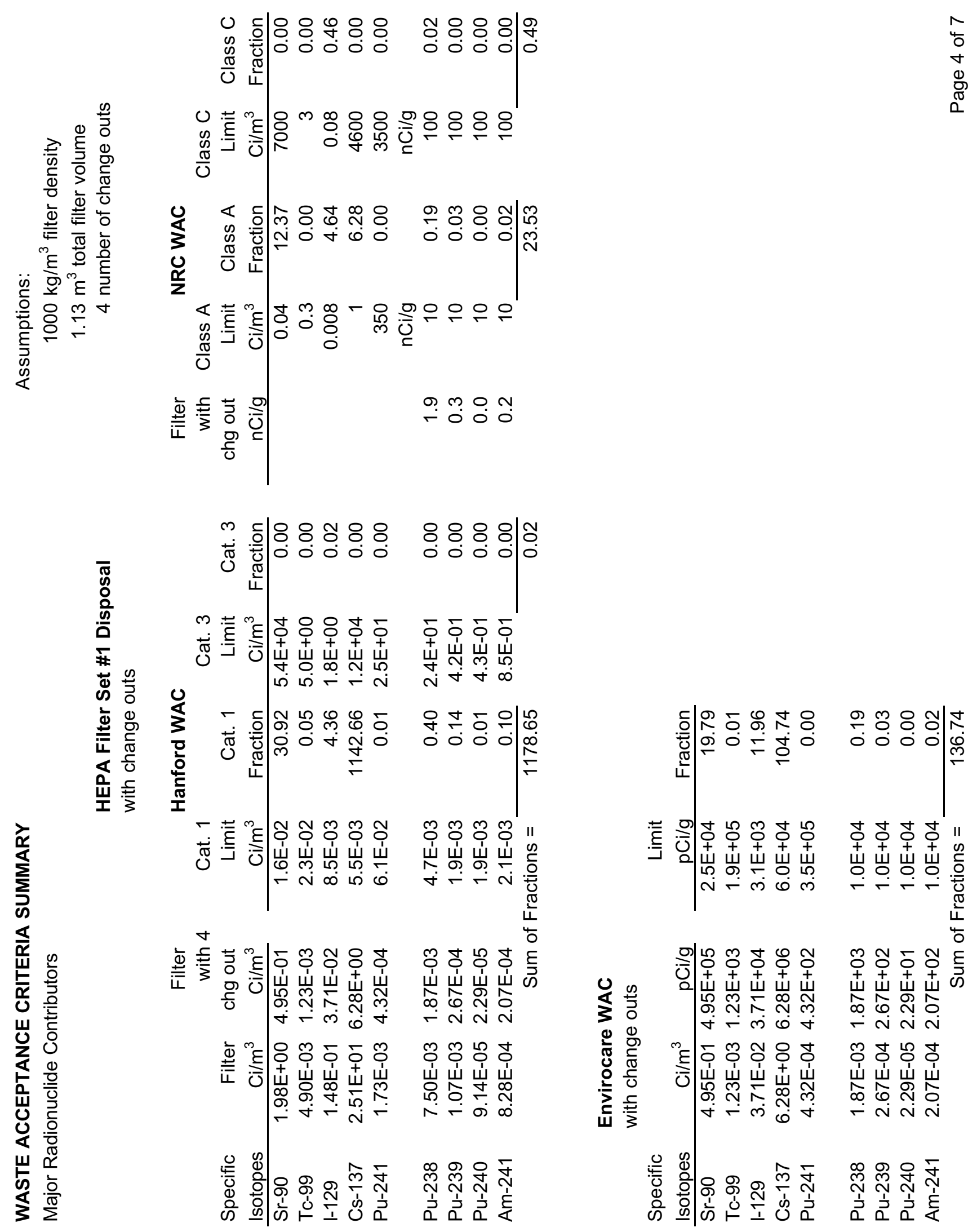


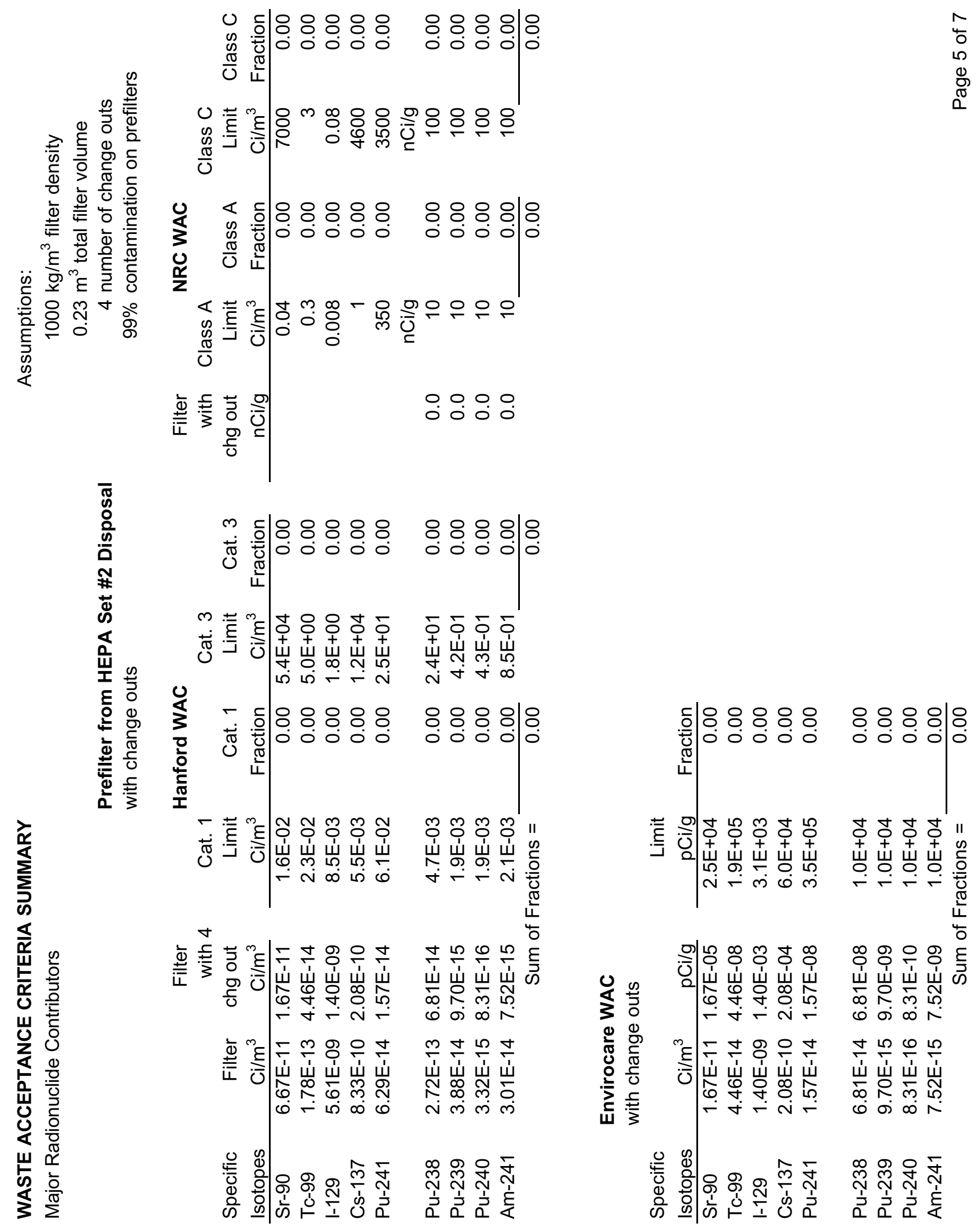




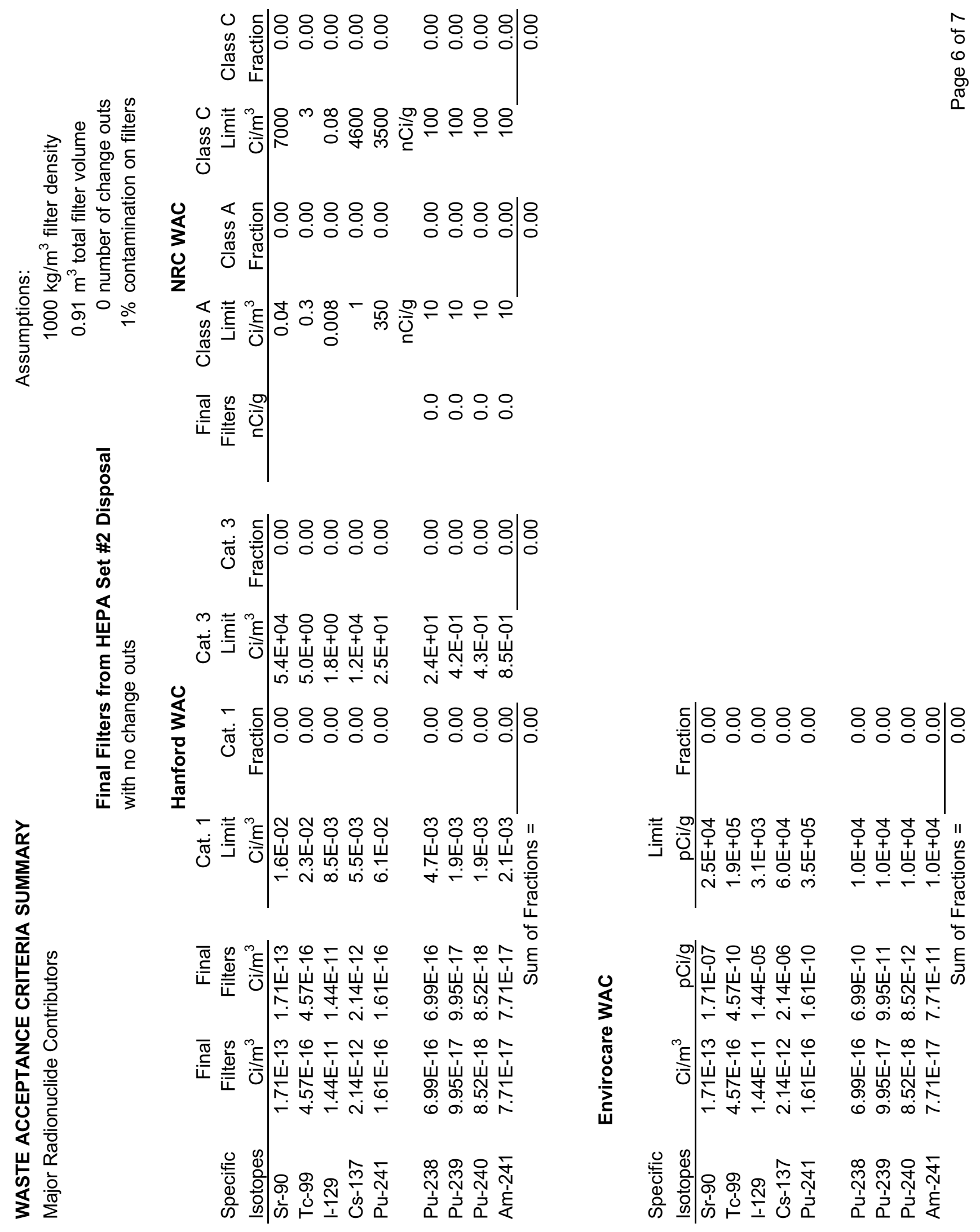




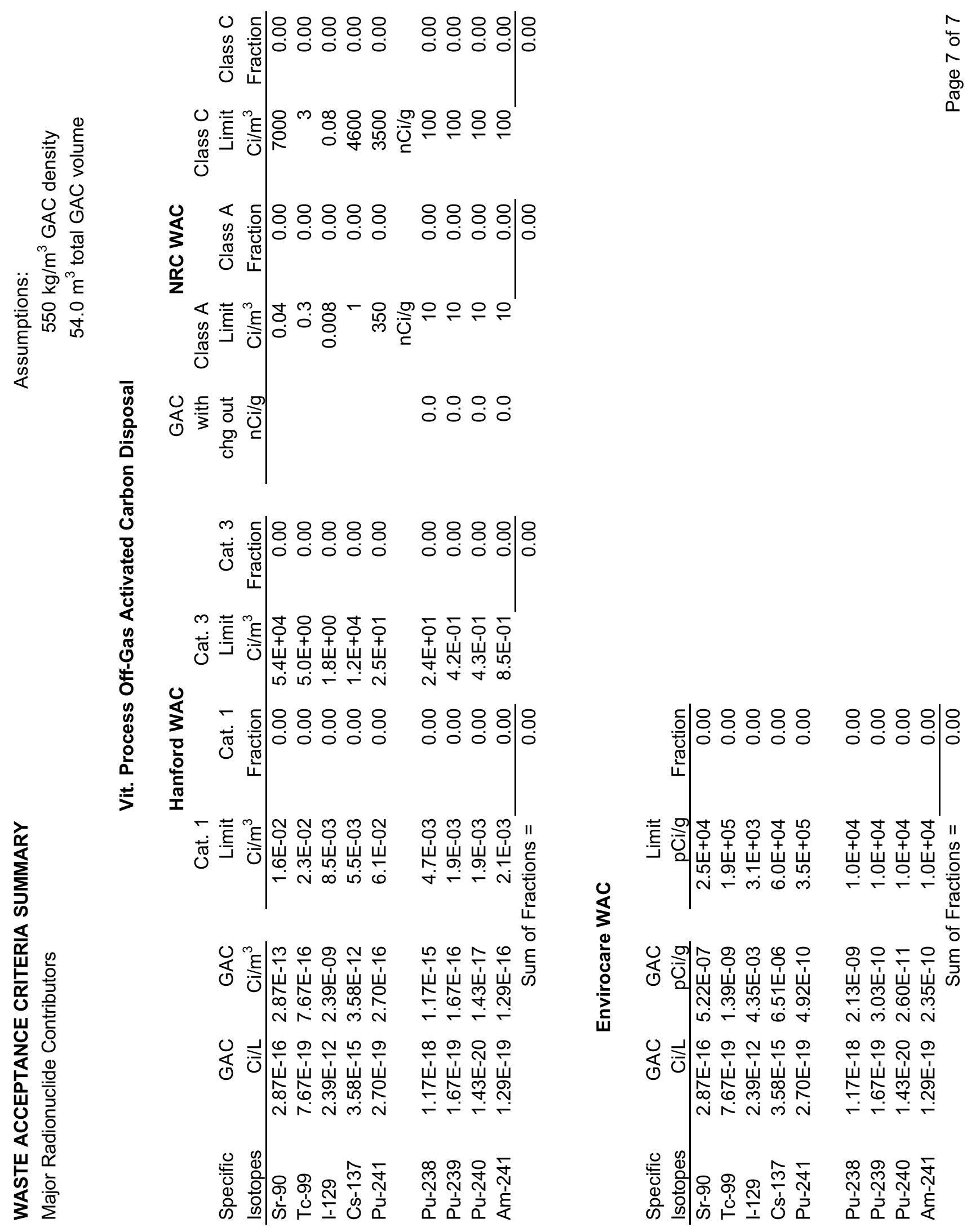





\section{APPENDIX C}

\section{RADIOLOGICAL ESTIMATES}



Page : 1

DOS File : SB1-1115.MS5

Run Date : January 7, 2002

Run Time: 14:12:46

Duration : 00:00:35
File Ref:

Date:

By:

Checked:

Case Title: Combined Scrub Drum

Description: Combined Scrub with CsIX -- 11/15/01

Geometry: 7 - Cylinder Volume - Side Shields

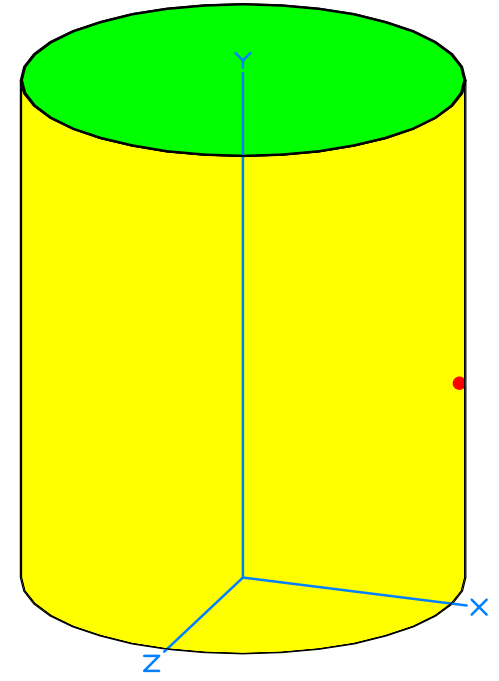

Source Dimensions

$69.84 \mathrm{~cm}$

$29.21 \mathrm{~cm}$

$2 \mathrm{ft} 3.5$ in

Radius

Dose Points

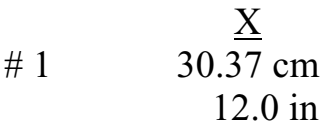

Y $31.04 \mathrm{~cm}$

$\underline{Z}$

$1 \mathrm{ft} 0.2$ in

$0 \mathrm{~cm}$

0.0 in

Shields

Shield Name

Dimension

Source

$1.87 \mathrm{e}+05 \mathrm{~cm}^{3}$

Material Density

Mixed -> 1.9

Concrete $\quad 1.8$

Shield 1

Transition

$.16 \mathrm{~cm}$

Water $\quad 0.1$

Air Gap

$1.0 \mathrm{~cm}$

Iron

7.86

Air $\quad 0.00122$

Air $\quad 0.00122$

Source Input

Grouping Method : Standard Indices

Number of Groups : 25

Lower Energy Cutoff : 0.015

Photons $<0.015$ : Excluded

Library : ICRP-38

\begin{tabular}{lc} 
Nuclide & $\underline{\text { curies }}$ \\
\hline Am-241 & $8.5365 \mathrm{e}-009$ \\
Ba-137m & $7.5069 \mathrm{e}-004$ \\
Cs-137 & $8.1996 \mathrm{e}-004$ \\
$\mathrm{I}-129$ & $1.1794 \mathrm{e}-004$ \\
Pu-238 & $7.7316 \mathrm{e}-008$ \\
Pu-239 & $1.1008 \mathrm{e}-008$ \\
Pu-240 & $9.4351 \mathrm{e}-010$ \\
Pu-241 & $1.7841 \mathrm{e}-008$ \\
Sr-90 & $6.4586 \mathrm{e}-001$ \\
Tc-99 & $5.0545 \mathrm{e}-008$ \\
Y-90 & $6.4586 \mathrm{e}-001$
\end{tabular}

becquerels

$3.1585 \mathrm{e}+002$

$2.7776 \mathrm{e}+007$

$3.0338 \mathrm{e}+007$

$4.3637 \mathrm{e}+006$

$2.8607 \mathrm{e}+003$

$4.0728 \mathrm{e}+002$

$3.4910 \mathrm{e}+001$

$6.6010 \mathrm{e}+002$

$2.3897 \mathrm{e}+010$

$1.8702 \mathrm{e}+003$

$2.3897 \mathrm{e}+010$ $\underline{\mu \mathrm{Ci} / \mathrm{cm}^{3}}$

$4.5600 \mathrm{e}-008$

$4.0100 \mathrm{e}-003$

$4.3800 \mathrm{e}-003$

$6.3000 \mathrm{e}-004$

$4.1300 \mathrm{e}-007$

$5.8800 \mathrm{e}-008$

$5.0400 \mathrm{e}-009$

$9.5300 \mathrm{e}-008$

$3.4500 \mathrm{e}+000$

$2.7000 \mathrm{e}-007$

$3.4500 \mathrm{e}+000$
$\underline{\mathrm{Bq} / \mathrm{cm}^{3}}$
$1.6872 \mathrm{e}-003$
$1.4837 \mathrm{e}+002$
$1.6206 \mathrm{e}+002$
$2.3310 \mathrm{e}+001$
$1.5281 \mathrm{e}-002$
$2.1756 \mathrm{e}-003$
$1.8648 \mathrm{e}-004$
$3.5261 \mathrm{e}-003$
$1.2765 \mathrm{e}+005$
$9.9900 \mathrm{e}-003$
$1.2765 \mathrm{e}+005$

Buildup

The material reference is : Source

Radial

Integration Parameters

Circumferential

Y Direction (axial)

\section{Results}


Page : 2

DOS File : SB1-1115.MS5

Run Date : January 7, 2002

Run Time: 14:12:46

Duration : 00:00:35

\begin{tabular}{|c|c|c|c|c|c|}
\hline$\frac{\text { Energy }}{\underline{\mathrm{MeV}}}$ & $\begin{array}{c}\text { Activity } \\
\text { photons/sec }\end{array}$ & $\frac{\frac{\text { Fluence Rate }}{\mathrm{MeV} / \mathrm{cm}^{2} / \mathrm{sec}}}{\text { No Buildup }}$ & $\frac{\frac{\text { Fluence Rate }}{\mathrm{MeV} / \mathrm{cm}^{2} / \mathrm{sec}}}{\text { With Buildup }}$ & 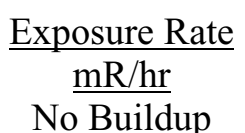 & $\frac{\frac{\text { Exposure Rate }}{\mathrm{mR} / \mathrm{hr}}}{\text { With Buildup }}$ \\
\hline 0.015 & $2.107 \mathrm{e}+06$ & $1.190 \mathrm{e}-36$ & $3.805 \mathrm{e}-26$ & $1.021 \mathrm{e}-37$ & $3.264 \mathrm{e}-27$ \\
\hline 0.02 & $3.975 \mathrm{e}+05$ & $1.472 \mathrm{e}-18$ & $3.622 \mathrm{e}-18$ & $5.098 \mathrm{e}-20$ & $1.255 \mathrm{e}-19$ \\
\hline 0.03 & $4.738 \mathrm{e}+06$ & $8.618 \mathrm{e}-07$ & $4.420 \mathrm{e}-06$ & $8.541 \mathrm{e}-09$ & $4.381 \mathrm{e}-08$ \\
\hline 0.04 & $7.275 \mathrm{e}+05$ & $1.503 \mathrm{e}-04$ & $1.311 \mathrm{e}-03$ & $6.649 \mathrm{e}-07$ & $5.800 \mathrm{e}-06$ \\
\hline 0.05 & $1.034 \mathrm{e}-01$ & $4.735 \mathrm{e}-10$ & $5.370 \mathrm{e}-09$ & $1.261 \mathrm{e}-12$ & $1.430 \mathrm{e}-11$ \\
\hline 0.06 & $1.129 \mathrm{e}+02$ & $2.703 \mathrm{e}-06$ & $3.225 \mathrm{e}-05$ & $5.369 \mathrm{e}-09$ & $6.405 \mathrm{e}-08$ \\
\hline 0.08 & $7.903 \mathrm{e}-02$ & $9.922 \mathrm{e}-09$ & $1.037 \mathrm{e}-07$ & $1.570 \mathrm{e}-11$ & $1.641 \mathrm{e}-10$ \\
\hline 0.1 & $4.196 \mathrm{e}-01$ & $1.183 \mathrm{e}-07$ & $1.039 \mathrm{e}-06$ & $1.810 \mathrm{e}-10$ & $1.590 \mathrm{e}-09$ \\
\hline 0.15 & $7.364 \mathrm{e}-02$ & $5.434 \mathrm{e}-08$ & $3.490 \mathrm{e}-07$ & $8.949 \mathrm{e}-11$ & $5.747 \mathrm{e}-10$ \\
\hline 0.2 & $6.835 \mathrm{e}-03$ & $8.387 \mathrm{e}-09$ & $4.374 \mathrm{e}-08$ & $1.480 \mathrm{e}-11$ & $7.720 \mathrm{e}-11$ \\
\hline 0.3 & $9.705 e-03$ & $2.256 \mathrm{e}-08$ & $9.223 \mathrm{e}-08$ & $4.279 \mathrm{e}-11$ & $1.749 \mathrm{e}-10$ \\
\hline 0.4 & $2.136 \mathrm{e}-02$ & $7.689 \mathrm{e}-08$ & $2.701 \mathrm{e}-07$ & $1.498 \mathrm{e}-10$ & $5.262 \mathrm{e}-10$ \\
\hline 0.5 & $1.159 \mathrm{e}-03$ & $5.848 \mathrm{e}-09$ & $1.836 \mathrm{e}-08$ & $1.148 \mathrm{e}-11$ & $3.605 \mathrm{e}-11$ \\
\hline 0.6 & $2.494 \mathrm{e}+07$ & $1.660 \mathrm{e}+02$ & $4.782 \mathrm{e}+02$ & $3.240 \mathrm{e}-01$ & $9.334 \mathrm{e}-01$ \\
\hline 0.8 & $2.372 \mathrm{e}-03$ & $2.450 \mathrm{e}-08$ & $6.211 \mathrm{e}-08$ & $4.661 \mathrm{e}-11$ & $1.181 \mathrm{e}-10$ \\
\hline 1.0 & $1.076 \mathrm{e}-04$ & $1.567 \mathrm{e}-09$ & $3.641 \mathrm{e}-09$ & $2.888 \mathrm{e}-12$ & $6.712 \mathrm{e}-12$ \\
\hline OTALS: & $3.291 \mathrm{e}+07$ & $1.660 \mathrm{e}+02$ & $4.782 \mathrm{e}+02$ & $3.240 \mathrm{e}-01$ & $9.335 \mathrm{e}-01$ \\
\hline
\end{tabular}


Page : 1

DOS File : SB2-1115.MS5

Run Date : January 7, 2002

Run Time: 14:15:30

Duration : 00:00:35
File Ref:

Date:

By:

Checked:

Case Title: Combined Scrub Drum

Description: Combined Scrub without CsIX -- 11/15/01

Geometry: 7 - Cylinder Volume - Side Shields

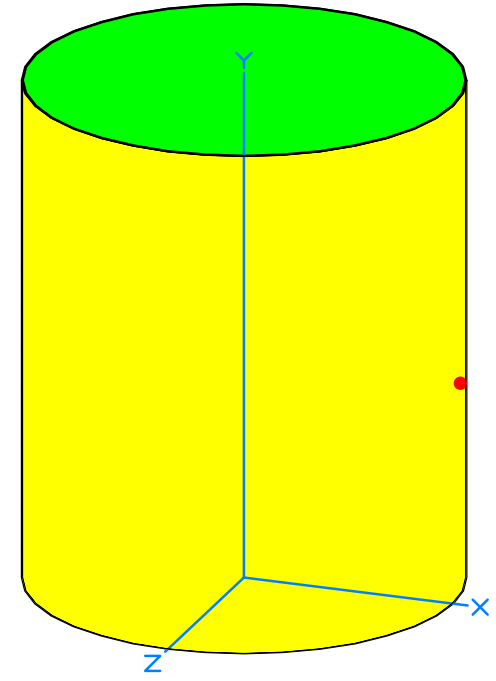

Source Dimensions

$\begin{array}{lr}69.84 \mathrm{~cm} & 2 \mathrm{ft} 3.5 \mathrm{in} \\ 29.21 \mathrm{~cm} & 11.5 \mathrm{in}\end{array}$

Height

Radius

$29.21 \mathrm{~cm}$

Dose Points

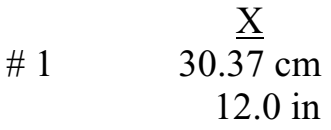

$\underline{Z}$

$0 \mathrm{~cm}$

0.0 in

\begin{tabular}{|c|c|c|c|}
\hline & Shields & & \\
\hline Shield Name & Dimension & Material & Density \\
\hline \multirow[t]{3}{*}{ Source } & $1.87 \mathrm{e}+05 \mathrm{~cm}^{3}$ & $\overline{\text { Mixed -> }}$ & 1.9 \\
\hline & & Concrete & 1.8 \\
\hline & & Water & 0.1 \\
\hline Shield 1 & $.16 \mathrm{~cm}$ & Iron & 7.86 \\
\hline Transition & $1.0 \mathrm{~cm}$ & Air & 0.00122 \\
\hline Air Gap & & Air & 0.00122 \\
\hline
\end{tabular}

Source Input

Grouping Method : Standard Indices

Number of Groups : 25

Lower Energy Cutoff : 0.015

Photons $<0.015$ : Excluded

Library : ICRP-38

\begin{tabular}{|c|c|c|c|}
\hline Nuclide & curies & becquerels & $\mu \mathrm{Ci} / \mathrm{cm}^{3}$ \\
\hline Am-241 & $8.5365 \mathrm{e}-009$ & $3.1585 \mathrm{e}+002$ & $4.5600 \mathrm{e}-008$ \\
\hline Ba-137m & $7.5069 \mathrm{e}+000$ & $2.7776 \mathrm{e}+011$ & $4.0100 \mathrm{e}+001$ \\
\hline Cs-137 & $8.1996 \mathrm{e}+000$ & $3.0338 \mathrm{e}+011$ & $4.3800 \mathrm{e}+001$ \\
\hline $\mathrm{I}-129$ & $1.1794 \mathrm{e}-004$ & $4.3637 \mathrm{e}+006$ & $6.3000 \mathrm{e}-004$ \\
\hline $\mathrm{Pu}-238$ & $7.7316 \mathrm{e}-008$ & $2.8607 \mathrm{e}+003$ & $4.1300 \mathrm{e}-007$ \\
\hline $\mathrm{Pu}-239$ & $1.1008 \mathrm{e}-008$ & $4.0728 \mathrm{e}+002$ & $5.8800 \mathrm{e}-008$ \\
\hline $\mathrm{Pu}-240$ & $9.4351 \mathrm{e}-010$ & $3.4910 \mathrm{e}+001$ & $5.0400 \mathrm{e}-009$ \\
\hline $\mathrm{Pu}-241$ & $1.7841 \mathrm{e}-008$ & $6.6010 \mathrm{e}+002$ & $9.5300 \mathrm{e}-008$ \\
\hline Sr-90 & $6.4586 \mathrm{e}-001$ & $2.3897 \mathrm{e}+010$ & $3.4500 \mathrm{e}+000$ \\
\hline Tc-99 & $5.0545 \mathrm{e}-008$ & $1.8702 \mathrm{e}+003$ & $2.7000 \mathrm{e}-007$ \\
\hline$Y-90$ & $6.4586 \mathrm{e}-001$ & $2.3897 \mathrm{e}+010$ & $3.4500 \mathrm{e}+000$ \\
\hline & \multicolumn{3}{|c|}{$\begin{array}{l}\text { Buildup } \\
\text { The material reference is : Source }\end{array}$} \\
\hline & \multicolumn{3}{|c|}{ Integration Parameters } \\
\hline & Radial & & \\
\hline & Circumferentia & & \\
\hline & Y Direction (a) & & \\
\hline
\end{tabular}

Results 
Page : 2

DOS File : SB2-1115.MS5

Run Date : January 7, 2002

Run Time: 14:15:30

Duration : 00:00:35

\begin{tabular}{|c|c|c|c|c|c|}
\hline$\frac{\text { Energy }}{\mathrm{MeV}}$ & $\begin{array}{c}\text { Activity } \\
\text { photons/sec }\end{array}$ & $\frac{\text { Fluence Rate }}{\mathrm{MeV} / \mathrm{cm}^{2} / \mathrm{sec}}$ & $\frac{\text { Fluence Rate }}{\mathrm{MeV} / \mathrm{cm}^{2} / \mathrm{sec}}$ & $\frac{\text { Exposure Rate }}{\underline{\mathrm{mR} / \mathrm{hr}}}$ & $\frac{\text { Exposure Rate }}{\mathrm{mR} / \mathrm{hr}}$ \\
\hline & & No Buildup & With Buildup & No Buildup & With Buildup \\
\hline 0.015 & $2.107 \mathrm{e}+06$ & $1.190 \mathrm{e}-36$ & $3.805 e-26$ & $1.021 \mathrm{e}-37$ & $3.264 \mathrm{e}-27$ \\
\hline 0.02 & $3.975 \mathrm{e}+05$ & $1.472 \mathrm{e}-18$ & $3.622 \mathrm{e}-18$ & $5.098 \mathrm{e}-20$ & $1.255 \mathrm{e}-19$ \\
\hline 0.03 & $1.682 \mathrm{e}+10$ & $3.060 \mathrm{e}-03$ & $1.569 \mathrm{e}-02$ & $3.032 \mathrm{e}-05$ & $1.555 \mathrm{e}-04$ \\
\hline 0.04 & $3.997 \mathrm{e}+09$ & $8.260 \mathrm{e}-01$ & $7.204 \mathrm{e}+00$ & $3.653 e-03$ & $3.186 \mathrm{e}-02$ \\
\hline 0.05 & $1.034 \mathrm{e}-01$ & $4.735 \mathrm{e}-10$ & $5.370 \mathrm{e}-09$ & $1.261 \mathrm{e}-12$ & $1.430 \mathrm{e}-11$ \\
\hline 0.06 & $1.129 \mathrm{e}+02$ & $2.703 e-06$ & $3.225 \mathrm{e}-05$ & $5.369 \mathrm{e}-09$ & $6.405 \mathrm{e}-08$ \\
\hline 0.08 & $7.903 e-02$ & $9.922 \mathrm{e}-09$ & $1.037 \mathrm{e}-07$ & $1.570 \mathrm{e}-11$ & $1.641 \mathrm{e}-10$ \\
\hline 0.1 & $4.196 \mathrm{e}-01$ & $1.183 \mathrm{e}-07$ & $1.039 \mathrm{e}-06$ & $1.810 \mathrm{e}-10$ & $1.590 \mathrm{e}-09$ \\
\hline 0.15 & $7.364 \mathrm{e}-02$ & $5.434 \mathrm{e}-08$ & $3.490 \mathrm{e}-07$ & $8.949 \mathrm{e}-11$ & $5.747 \mathrm{e}-10$ \\
\hline 0.2 & $6.835 \mathrm{e}-03$ & 8.387e-09 & $4.374 \mathrm{e}-08$ & $1.480 \mathrm{e}-11$ & $7.720 \mathrm{e}-11$ \\
\hline 0.3 & $9.705 e-03$ & $2.256 \mathrm{e}-08$ & $9.223 \mathrm{e}-08$ & $4.279 \mathrm{e}-11$ & $1.749 \mathrm{e}-10$ \\
\hline 0.4 & $2.136 \mathrm{e}-02$ & $7.689 \mathrm{e}-08$ & $2.701 \mathrm{e}-07$ & $1.498 \mathrm{e}-10$ & $5.262 \mathrm{e}-10$ \\
\hline 0.5 & $1.159 \mathrm{e}-03$ & $5.848 \mathrm{e}-09$ & $1.836 \mathrm{e}-08$ & $1.148 \mathrm{e}-11$ & $3.605 \mathrm{e}-11$ \\
\hline 0.6 & $2.494 \mathrm{e}+11$ & $1.660 \mathrm{e}+06$ & $4.782 \mathrm{e}+06$ & $3.240 \mathrm{e}+03$ & $9.334 \mathrm{e}+03$ \\
\hline 0.8 & $2.372 \mathrm{e}-03$ & $2.450 \mathrm{e}-08$ & $6.211 \mathrm{e}-08$ & $4.661 \mathrm{e}-11$ & $1.181 \mathrm{e}-10$ \\
\hline 1.0 & $1.076 \mathrm{e}-04$ & $1.567 \mathrm{e}-09$ & $3.641 \mathrm{e}-09$ & $2.888 \mathrm{e}-12$ & $6.712 \mathrm{e}-12$ \\
\hline OTALS: & $2.702 \mathrm{e}+11$ & $1.660 \mathrm{e}+06$ & $4.782 \mathrm{e}+06$ & $3.240 \mathrm{e}+03$ & $9.334 \mathrm{e}+03$ \\
\hline
\end{tabular}


Page : 1

DOS File : CSIX1115.MS5

Run Date : January 7, 2002

Run Time: 14:35:06

Duration : 00:00:19
File Ref:

Date:

By:

Checked:

Case Title: IX Media Drum

Description: Ion Exchange Media with Cesium -- 11/15/01

Geometry: 7 - Cylinder Volume - Side Shields

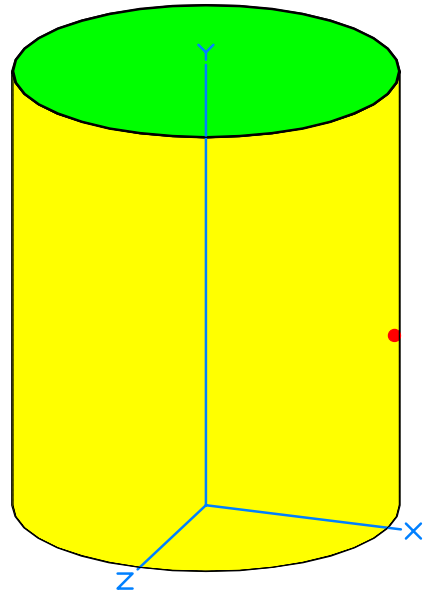

Source Dimensions

Height

Radius

$69.84 \mathrm{~cm}$

$29.21 \mathrm{~cm}$

$2 \mathrm{ft} 3.5$ in

11.5 in

Dose Points

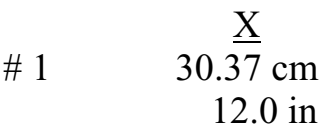

$\frac{\mathrm{Y}}{31.04 \mathrm{~cm}}$
$1 \mathrm{ft} 0.2 \mathrm{in}$

Shields

Shield Name

Dimension

Source

Shield 1

Transition

Air Gap
$1.87 \mathrm{e}+05 \mathrm{~cm}^{3}$
$.16 \mathrm{~cm}$
$1.0 \mathrm{~cm}$

$\underline{\text { Material }}$

Density

Iron $\quad 7.86$

Air $\quad 0.00122$

Air

0.00122

Source Input

Grouping Method : Standard Indices

Number of Groups : 25

Lower Energy Cutoff : 0.015

Photons $<0.015$ : Excluded

Library : ICRP-38

$\begin{array}{lc}\text { Nuclide } & \underline{\text { curies }} \\ \text { Ba-137m } & 7.0389 \mathrm{e}+001 \\ \text { Cs-134 } & 8.1621 \mathrm{e}-004 \\ \text { Cs-135 } & 1.7635 \mathrm{e}-003 \\ \text { Cs-137 } & 7.6754 \mathrm{e}+001\end{array}$

$\frac{\mu \mathrm{Ci} / \mathrm{cm}^{3}}{3.7600 \mathrm{e}+002}$
$4.3600 \mathrm{e}-003$
$9.4200 \mathrm{e}-003$
$4.1000 \mathrm{e}+002$

$\frac{\mu \mathrm{Ci} / \mathrm{cm}^{3}}{3.7600 \mathrm{e}+002}$

$\underline{\mathrm{Bq} / \mathrm{cm}^{3}}$

$2.6044 \mathrm{e}+012$

$3.0200 \mathrm{e}+007$

$6.5248 \mathrm{e}+007$

$2.8399 \mathrm{e}+012$

Buildup

The material reference is : Source

Radial

\section{Integration Parameters}

Circumferential

Y Direction (axial)

Activity

Energy

$\underline{\mathrm{MeV}}$

photons/sec

0.03

$1.577 \mathrm{e}+11$

$3.747 \mathrm{e}+10$

$6.342 \mathrm{e}+03$
Fluence Rate

$\mathrm{MeV} / \mathrm{cm}^{2} / \mathrm{sec}$

No Buildup

3.239e-01

$6.302 \mathrm{e}+01$

2.247e-02

\section{Results}

Fluence Rate $\mathrm{MeV} / \mathrm{cm}^{2} / \mathrm{sec}$

With Buildup

$1.527 \mathrm{e}+01$

$4.610 \mathrm{e}+03$

$1.350 \mathrm{e}-01$
26

26

26
0.2 
Page : 2

DOS File : CSIX1115.MS5

Run Date : January 7, 2002

Run Time: 14:35:06

Duration : 00:00:19

\begin{tabular}{|c|c|c|c|c|c|}
\hline$\frac{\text { Energy }}{\mathrm{MeV}}$ & Activity & $\frac{\text { Fluence Rate }}{\mathrm{MeV} / \mathrm{cm}^{2} / \mathrm{sec}^{2}}$ & $\frac{\text { Fluence Rate }}{\mathrm{MeV} / \mathrm{cm}^{2} / \mathrm{sec}}$ & $\frac{\text { Exposure Rate }}{\mathrm{mR} / \mathrm{hr}}$ & $\frac{\text { Exposure Rate }}{\mathrm{mR} / \mathrm{hr}}$ \\
\hline & & $\frac{1 \mathrm{NeV} / \mathrm{cm}^{2} \mathrm{sec}}{\text { No Buildup }}$ & With Buildup & $\frac{\mathrm{mR} / \mathrm{hr}}{\text { No Buildup }}$ & With Buildup \\
\hline 0.3 & $4.349 \mathrm{e}+03$ & $2.817 \mathrm{e}-02$ & $1.153 \mathrm{e}-01$ & $5.343 \mathrm{e}-05$ & $2.188 \mathrm{e}-04$ \\
\hline 0.5 & $4.409 \mathrm{e}+05$ & $5.919 \mathrm{e}+00$ & $1.665 \mathrm{e}+01$ & $1.162 \mathrm{e}-02$ & $3.268 \mathrm{e}-02$ \\
\hline 0.6 & $2.338 \mathrm{e}+12$ & $4.060 \mathrm{e}+07$ & $1.030 \mathrm{e}+08$ & $7.925 e+04$ & $2.010 \mathrm{e}+05$ \\
\hline 0.8 & $2.843 \mathrm{e}+07$ & $7.390 \mathrm{e}+02$ & $1.577 \mathrm{e}+03$ & $1.406 \mathrm{e}+00$ & $3.000 \mathrm{e}+00$ \\
\hline 1.0 & $8.456 \mathrm{e}+05$ & $3.001 \mathrm{e}+01$ & $5.767 \mathrm{e}+01$ & $5.532 \mathrm{e}-02$ & $1.063 \mathrm{e}-01$ \\
\hline 1.5 & $9.181 \mathrm{e}+05$ & $5.688 \mathrm{e}+01$ & $9.420 \mathrm{e}+01$ & $9.570 \mathrm{e}-02$ & $1.585 \mathrm{e}-01$ \\
\hline OTALS: & $2.533 \mathrm{e}+12$ & $4.060 \mathrm{e}+07$ & $1.030 \mathrm{e}+08$ & $7.925 e+04$ & $2.010 \mathrm{e}+05$ \\
\hline
\end{tabular}


Page : 1

DOS File : FT1-1115.MS5

Run Date : January 7, 2002

Run Time: 13:45:05

Duration : 00:00:14
File Ref:

Date:

By:

Checked:

Case Title: HEPA Filter Set \#1

Description: Vit. Process Off-Gas Filter Set \#1 - 4 Change Outs -11/15/01

Geometry: 13 - Rectangular Volume

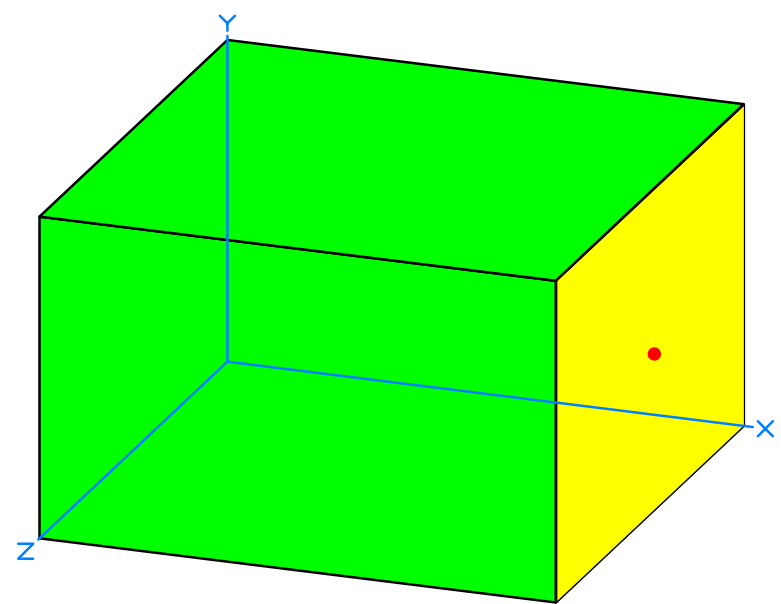

Length

Width

Height

\# $1 \quad \begin{aligned} & \text { X } \\ & \begin{array}{r}123.16 \mathrm{~cm} \\ 4 \mathrm{ft} 0.5 \mathrm{in}\end{array}\end{aligned}$
Source Dimensions

$122.0 \mathrm{~cm}$

$122.0 \mathrm{~cm}$

$76.0 \mathrm{~cm}$

Dose Points

$$
\frac{\mathrm{Y}}{38} \mathrm{~cm}
$$$$
1 \mathrm{ft} 3.0 \text { in }
$$

$4 \mathrm{ft} 0.0$ in

$4 \mathrm{ft} 0.0$ in

$2 \mathrm{ft} 5.9$ in

\begin{tabular}{lccll} 
Shield Name & $\begin{array}{c}\text { Shields } \\
\text { Dimension }\end{array}$ & Material & & Density \\
\cline { 1 - 2 } Source & & $1.13 \mathrm{e}+06 \mathrm{~cm}^{3}$ & Air & 0.00122 \\
Shield 1 & $.16 \mathrm{~cm}$ & Iron & 7.86 \\
Air Gap & & Air & 0.00122
\end{tabular}

Source Input

Grouping Method : Standard Indices

Number of Groups : 25

Lower Energy Cutoff : 0.015

Photons $<0.015$ : Excluded

Library : ICRP-38

$\underline{\text { Nuclide }}$

Am-241

Ba- $137 \mathrm{~m}$

Cs-137

I-129

$\mathrm{Pu}-238$

$\mathrm{Pu}-239$

$\mathrm{Pu}-240$

$\mathrm{Pu}-241$

Sr-90

Tc-99

$\mathrm{Y}-90$ curies

$2.3416 \mathrm{e}-004$

$6.5043 \mathrm{e}+000$

$7.1038 \mathrm{e}+000$

4.1967e-002

$2.1153 \mathrm{e}-003$

$3.0203 \mathrm{e}-004$

2.5904e-005

4.8867e-004

5.5994e-001

$1.3914 \mathrm{e}-003$

5.5994e-001 becquerels

$8.6639 \mathrm{e}+006$

$2.4066 \mathrm{e}+011$

$2.6284 \mathrm{e}+011$

$1.5528 \mathrm{e}+009$

$7.8267 \mathrm{e}+007$

$1.1175 \mathrm{e}+007$

$9.5845 \mathrm{e}+005$

$1.8081 \mathrm{e}+007$

$2.0718 \mathrm{e}+010$

$5.1480 \mathrm{e}+007$

$2.0718 \mathrm{e}+010$ $\mu \mathrm{Ci} / \mathrm{cm}^{3}$

2.0700e-004

$5.7500 \mathrm{e}+000$

$6.2800 \mathrm{e}+000$

$3.7100 \mathrm{e}-002$

$1.8700 \mathrm{e}-003$

2.6700e-004

$2.2900 \mathrm{e}-005$

$4.3200 \mathrm{e}-004$

$4.9500 \mathrm{e}-001$

$1.2300 \mathrm{e}-003$

$4.9500 \mathrm{e}-001$
$\underline{\mathrm{Bq} / \mathrm{cm}^{3}}$

7.6592e+000

$2.1275 \mathrm{e}+005$

$2.3236 \mathrm{e}+005$

$1.3727 \mathrm{e}+003$

$6.9190 \mathrm{e}+001$

$9.8790 \mathrm{e}+000$

$8.4730 \mathrm{e}-001$

$1.5984 \mathrm{e}+001$

$1.8315 \mathrm{e}+004$

$4.5510 \mathrm{e}+001$

$1.8315 \mathrm{e}+004$

Buildup

The material reference is : Source

X Direction

Integration Parameters

Y Direction

Z Direction

\section{Results}


Page : 2

DOS File : FT1-1115.MS5

Run Date : January 7, 2002

Run Time: 13:45:05

Duration : 00:00:14

\begin{tabular}{|c|c|c|c|c|c|}
\hline$\frac{\text { Energy }}{\mathrm{MeV}}$ & $\begin{array}{c}\text { Activity } \\
\text { photons/sec }\end{array}$ & $\frac{\text { Fluence Rate }}{\mathrm{MeV} / \mathrm{cm}^{2} / \mathrm{sec}}$ & $\frac{\text { Fluence Rate }}{\mathrm{MeV} / \mathrm{cm}^{2} / \mathrm{sec}}$ & $\frac{\text { Exposure Rate }}{\underline{\mathrm{mR} / \mathrm{hr}}}$ & $\frac{\text { Exposure Rate }}{\mathrm{mR} / \mathrm{hr}}$ \\
\hline & & No Buildup & With Buildup & No Buildup & With Buildup \\
\hline 0.015 & $7.344 \mathrm{e}+06$ & $1.133 \mathrm{e}-32$ & $5.267 e-26$ & $9.721 e-34$ & $4.518 \mathrm{e}-27$ \\
\hline 0.02 & $3.957 \mathrm{e}+06$ & $2.046 e-15$ & $7.492 \mathrm{e}-15$ & $7.087 e-17$ & $2.595 \mathrm{e}-16$ \\
\hline 0.03 & $1.566 \mathrm{e}+10$ & $9.388 \mathrm{e}-02$ & $8.607 \mathrm{e}-01$ & $9.304 \mathrm{e}-04$ & $8.530 \mathrm{e}-03$ \\
\hline 0.04 & $3.579 \mathrm{e}+09$ & $1.371 \mathrm{e}+01$ & $1.932 \mathrm{e}+02$ & $6.061 \mathrm{e}-02$ & $8.547 \mathrm{e}-01$ \\
\hline 0.05 & $2.837 \mathrm{e}+03$ & $1.484 \mathrm{e}-04$ & $1.976 \mathrm{e}-03$ & $3.954 \mathrm{e}-07$ & $5.265 \mathrm{e}-06$ \\
\hline 0.06 & $3.097 \mathrm{e}+06$ & $6.049 \mathrm{e}-01$ & $6.081 \mathrm{e}+00$ & $1.201 \mathrm{e}-03$ & $1.208 \mathrm{e}-02$ \\
\hline 0.08 & $2.168 \mathrm{e}+03$ & $1.518 \mathrm{e}-03$ & $7.844 \mathrm{e}-03$ & $2.402 \mathrm{e}-06$ & $1.241 \mathrm{e}-05$ \\
\hline 0.1 & $1.149 \mathrm{e}+04$ & $1.492 \mathrm{e}-02$ & $4.834 \mathrm{e}-02$ & $2.282 \mathrm{e}-05$ & $7.395 \mathrm{e}-05$ \\
\hline 0.15 & $2.018 \mathrm{e}+03$ & $5.482 \mathrm{e}-03$ & $1.081 \mathrm{e}-02$ & $9.028 \mathrm{e}-06$ & $1.780 \mathrm{e}-05$ \\
\hline 0.2 & $1.875 \mathrm{e}+02$ & $7.521 \mathrm{e}-04$ & $1.195 \mathrm{e}-03$ & $1.327 \mathrm{e}-06$ & $2.110 \mathrm{e}-06$ \\
\hline 0.3 & $2.663 \mathrm{e}+02$ & $1.731 \mathrm{e}-03$ & $2.391 \mathrm{e}-03$ & $3.283 \mathrm{e}-06$ & $4.535 \mathrm{e}-06$ \\
\hline 0.4 & $5.861 \mathrm{e}+02$ & $5.267 \mathrm{e}-03$ & $6.816 \mathrm{e}-03$ & $1.026 \mathrm{e}-05$ & $1.328 \mathrm{e}-05$ \\
\hline 0.5 & $3.179 \mathrm{e}+01$ & $3.656 \mathrm{e}-04$ & $4.547 \mathrm{e}-04$ & 7.177e-07 & $8.925 \mathrm{e}-07$ \\
\hline 0.6 & $2.161 \mathrm{e}+11$ & $3.035 \mathrm{e}+06$ & $3.675 \mathrm{e}+06$ & $5.924 \mathrm{e}+03$ & $7.173 e+03$ \\
\hline 0.8 & $6.494 \mathrm{e}+01$ & $1.248 \mathrm{e}-03$ & $1.457 \mathrm{e}-03$ & $2.374 \mathrm{e}-06$ & $2.771 \mathrm{e}-06$ \\
\hline 1.0 & $2.943 \mathrm{e}+00$ & $7.206 \mathrm{e}-05$ & $8.229 \mathrm{e}-05$ & $1.328 \mathrm{e}-07$ & $1.517 \mathrm{e}-07$ \\
\hline OTALS: & $2.353 \mathrm{e}+11$ & $3.035 \mathrm{e}+06$ & $3.675 \mathrm{e}+06$ & $5.924 \mathrm{e}+03$ & $7.174 \mathrm{e}+03$ \\
\hline
\end{tabular}


Page : 1

DOS File : FT2-1115.MS5

Run Date : January 7, 2002

Run Time: 13:47:06

Duration : 00:00:14
File Ref:

Date:

By:

Checked:

Case Title: Prefilters Set \#2

Description: Vit. Process Off-Gas Final Prefilters -- 11/15/01

Geometry: 13 - Rectangular Volume

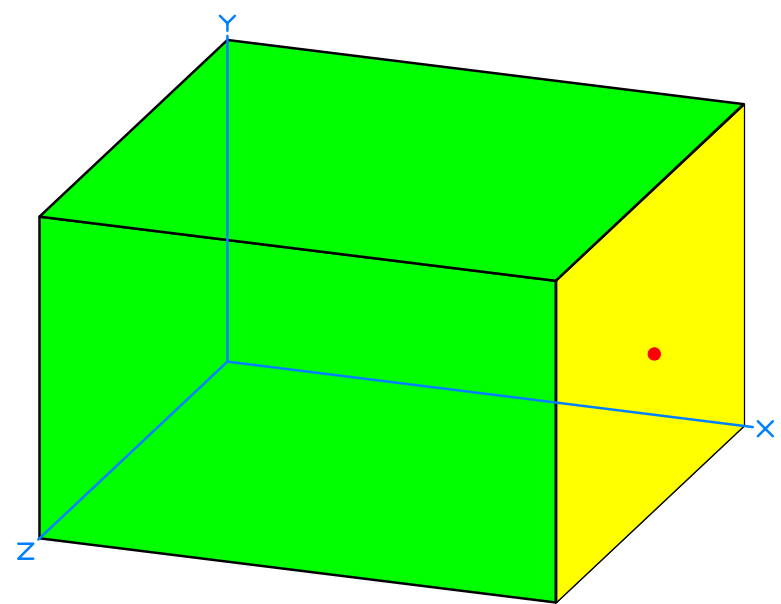

\author{
Length \\ Width \\ Height
\# $1 \quad \frac{X}{123.16 \mathrm{~cm}}$ $4 \mathrm{ft} 0.5$ in

Source Dimensions

$\begin{array}{rl}122.0 \mathrm{~cm} & 4 \mathrm{ft} 0.0 \mathrm{in} \\ 122.0 \mathrm{~cm} & 4 \mathrm{ft} 0.0 \mathrm{in} \\ 76.0 \mathrm{~cm} & 2 \mathrm{ft} 5.9 \mathrm{in}\end{array}$

Dose Points

$\begin{array}{cc}\frac{Y}{38} \mathrm{~cm} & \underline{Z} \\ 1 \mathrm{ft} 3.0 \mathrm{in} & 2 \mathrm{ft} 0.0 \mathrm{~cm}\end{array}$

Shields

Dimension

Shield Name

Source

Shield 1

Air Gap

\section{$1.13 \mathrm{e}+06 \mathrm{~cm}^{3}$}

$.16 \mathrm{~cm}$

$\begin{array}{cll}\text { Material } & & \text { Density } \\ \text { Air } & & 0.00122 \\ \text { Iron } & 7.86 \\ \text { Air } & 0.00122\end{array}$

Source Input

Grouping Method : Standard Indices

Number of Groups : 25

Lower Energy Cutoff : 0.015

Photons $<0.015$ : Excluded

Library : ICRP-38

$\begin{array}{lcccc}\text { Nuclide } & \underline{\text { curies }} & \underline{\text { becquerels }} & \underline{\mu \mathrm{Ci} / \mathrm{cm}^{3}} & \underline{\mathrm{Bq} / \mathrm{cm}^{3}} \\ \text { Am-241 } & 8.5065 \mathrm{e}-015 & 3.1474 \mathrm{e}-004 & 7.5200 \mathrm{e}-015 & 2.7824 \mathrm{e}-010 \\ \text { Ba-137m } & 2.1606 \mathrm{e}-010 & 7.9941 \mathrm{e}+000 & 1.9100 \mathrm{e}-010 & 7.0670 \mathrm{e}-006 \\ \mathrm{Cs}-137 & 2.3529 \mathrm{e}-010 & 8.7056 \mathrm{e}+000 & 2.0800 \mathrm{e}-010 & 7.6960 \mathrm{e}-006 \\ \mathrm{I}-129 & 1.5837 \mathrm{e}-009 & 5.8595 \mathrm{e}+001 & 1.4000 \mathrm{e}-009 & 5.1800 \mathrm{e}-005 \\ \text { Pu-238 } & 7.7034 \mathrm{e}-014 & 2.8502 \mathrm{e}-003 & 6.8100 \mathrm{e}-014 & 2.5197 \mathrm{e}-009 \\ \text { Pu-239 } & 1.0972 \mathrm{e}-014 & 4.0598 \mathrm{e}-004 & 9.7000 \mathrm{e}-015 & 3.5890 \mathrm{e}-010 \\ \mathrm{Pu}-240 & 9.4001 \mathrm{e}-016 & 3.4781 \mathrm{e}-005 & 8.3100 \mathrm{e}-016 & 3.0747 \mathrm{e}-011 \\ \text { Pu-241 } & 1.7760 \mathrm{e}-014 & 6.5710 \mathrm{e}-004 & 1.5700 \mathrm{e}-014 & 5.8090 \mathrm{e}-010 \\ \text { Sr-90 } & 1.8891 \mathrm{e}-011 & 6.9896 \mathrm{e}-001 & 1.6700 \mathrm{e}-011 & 6.1790 \mathrm{e}-007 \\ \text { Tc-99 } & 5.0451 \mathrm{e}-014 & 1.8667 \mathrm{e}-003 & 4.4600 \mathrm{e}-014 & 1.6502 \mathrm{e}-009 \\ \text { Y-90 } & 1.8891 \mathrm{e}-011 & 6.9896 \mathrm{e}-001 & 1.6700 \mathrm{e}-011 & 6.1790 \mathrm{e}-007\end{array}$

Buildup

The material reference is : Source

X Direction

Integration Parameters

Y Direction

Z Direction

\section{Results}


Page : 2

DOS File : FT2-1115.MS5

Run Date : January 7, 2002

Run Time: 13:47:06

Duration : 00:00:14

\begin{tabular}{|c|c|c|c|c|c|}
\hline$\frac{\text { Energy }}{\mathrm{MeV}}$ & 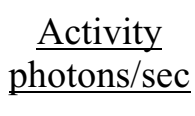 & $\begin{array}{l}\text { Fluence Rate } \\
\mathrm{MeV} / \mathrm{cm}^{2} / \mathrm{sec} \\
\end{array}$ & $\frac{\text { Fluence Rate }}{\mathrm{MeV} / \mathrm{cm}^{2} / \mathrm{sec}}$ & $\frac{\text { Exposure Rate }}{\mathrm{mR} / \mathrm{hr}}$ & $\frac{\text { Exposure Rate }}{\frac{\mathrm{mR} / \mathrm{hr}}{\text { With } \mathrm{Ruil}}}$ \\
\hline & & No Buildup & With Buildup & No Buildup & With Buildup \\
\hline 0.015 & $2.624 \mathrm{e}-04$ & $4.050 \mathrm{e}-43$ & $1.882 \mathrm{e}-36$ & $3.474 \mathrm{e}-44$ & $1.615 \mathrm{e}-37$ \\
\hline 0.02 & $1.430 \mathrm{e}-04$ & 7.391e-26 & $2.707 \mathrm{e}-25$ & $2.560 \mathrm{e}-27$ & $9.375 e-27$ \\
\hline 0.03 & $4.153 \mathrm{e}+01$ & $2.489 \mathrm{e}-10$ & $2.282 \mathrm{e}-09$ & $2.467 \mathrm{e}-12$ & $2.262 \mathrm{e}-11$ \\
\hline 0.04 & $4.518 \mathrm{e}+00$ & $1.730 \mathrm{e}-08$ & $2.439 \mathrm{e}-07$ & $7.650 \mathrm{e}-11$ & $1.079 \mathrm{e}-09$ \\
\hline 0.05 & $1.031 \mathrm{e}-07$ & $5.391 \mathrm{e}-15$ & $7.179 \mathrm{e}-14$ & $1.436 \mathrm{e}-17$ & $1.912 \mathrm{e}-16$ \\
\hline 0.06 & $1.125 \mathrm{e}-04$ & $2.197 \mathrm{e}-11$ & $2.209 \mathrm{e}-10$ & $4.364 \mathrm{e}-14$ & $4.388 \mathrm{e}-13$ \\
\hline 0.08 & 7.876e-08 & $5.515 \mathrm{e}-14$ & $2.850 \mathrm{e}-13$ & $8.727 \mathrm{e}-17$ & $4.510 \mathrm{e}-16$ \\
\hline 0.1 & $4.181 \mathrm{e}-07$ & $5.427 \mathrm{e}-13$ & $1.758 \mathrm{e}-12$ & $8.302 \mathrm{e}-16$ & $2.690 \mathrm{e}-15$ \\
\hline 0.15 & $7.338 \mathrm{e}-08$ & $1.994 \mathrm{e}-13$ & $3.932 \mathrm{e}-13$ & $3.283 \mathrm{e}-16$ & $6.474 \mathrm{e}-16$ \\
\hline 0.2 & $6.812 \mathrm{e}-09$ & $2.732 \mathrm{e}-14$ & $4.343 \mathrm{e}-14$ & $4.822 \mathrm{e}-17$ & $7.665 \mathrm{e}-17$ \\
\hline 0.3 & $9.673 \mathrm{e}-09$ & $6.287 \mathrm{e}-14$ & $8.686 \mathrm{e}-14$ & $1.193 \mathrm{e}-16$ & $1.648 \mathrm{e}-16$ \\
\hline 0.4 & $2.129 \mathrm{e}-08$ & $1.913 \mathrm{e}-13$ & $2.476 \mathrm{e}-13$ & $3.728 \mathrm{e}-16$ & $4.825 \mathrm{e}-16$ \\
\hline 0.5 & $1.155 \mathrm{e}-09$ & $1.328 \mathrm{e}-14$ & $1.652 \mathrm{e}-14$ & $2.607 e-17$ & $3.243 e-17$ \\
\hline 0.6 & $7.177 \mathrm{e}+00$ & $1.008 \mathrm{e}-04$ & $1.221 \mathrm{e}-04$ & $1.968 \mathrm{e}-07$ & $2.383 \mathrm{e}-07$ \\
\hline 0.8 & $2.363 \mathrm{e}-09$ & $4.542 \mathrm{e}-14$ & $5.300 \mathrm{e}-14$ & $8.639 \mathrm{e}-17$ & $1.008 \mathrm{e}-16$ \\
\hline 1.0 & $1.072 \mathrm{e}-10$ & $2.624 \mathrm{e}-15$ & $2.997 \mathrm{e}-15$ & $4.836 \mathrm{e}-18$ & $5.523 \mathrm{e}-18$ \\
\hline OTALS: & $5.322 \mathrm{e}+01$ & $1.008 \mathrm{e}-04$ & $1.223 \mathrm{e}-04$ & $1.969 \mathrm{e}-07$ & $2.394 \mathrm{e}-07$ \\
\hline
\end{tabular}


Page : 1

DOS File : FT3-1115.MS5

Run Date : January 7, 2002

Run Time: 13:50:58

Duration : 00:00:14
File Ref:

Date:

By:

Checked:

Case Title: Final Filter Set \#2

Description: Vit. Process Off-Gas Final HEPA Filters -- 11/15/01

Geometry: 13 - Rectangular Volume

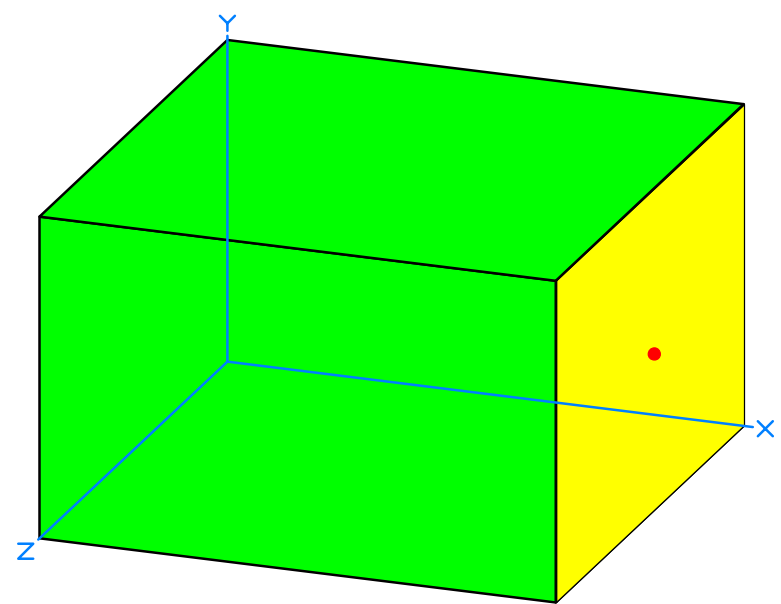

\section{Length \\ Width \\ Height}
$\# 1 \quad \frac{X}{123.16} \mathrm{~cm}$ $4 \mathrm{ft} 0.5$ in

Source Dimensions

$\begin{array}{rl}122.0 \mathrm{~cm} & 4 \mathrm{ft} 0.0 \mathrm{in} \\ 122.0 \mathrm{~cm} & 4 \mathrm{ft} 0.0 \mathrm{in} \\ 76.0 \mathrm{~cm} & 2 \mathrm{ft} 5.9 \mathrm{in}\end{array}$

Dose Points

$\begin{array}{cc}\frac{Y}{38} \mathrm{~cm} & \underline{Z} \\ 1 \mathrm{ft} 3.0 \mathrm{in} & 2 \mathrm{ft} 0.0 \mathrm{~cm}\end{array}$

Shields

Shield Name

Source

Shield 1

Air Gap
Dimension

$1.13 \mathrm{e}+06 \mathrm{~cm}^{3}$

$.16 \mathrm{~cm}$

$\begin{array}{cll}\text { Material } & & \text { Density } \\ \text { Air } & & 0.00122 \\ \text { Iron } & 7.86 \\ \text { Air } & 0.00122\end{array}$

Source Input

Grouping Method : Standard Indices

Number of Groups : 25

Lower Energy Cutoff : 0.015

Photons $<0.015$ : Excluded

Library : ICRP-38

$\begin{array}{lc}\text { Nuclide } & \underline{\text { curies }} \\ \text { Am-241 } & 8.7214 \mathrm{e}-017 \\ \text { Ba-137m } & 2.2171 \mathrm{e}-012 \\ \mathrm{Cs}-137 & 2.4207 \mathrm{e}-012 \\ \mathrm{I}-129 & 1.6289 \mathrm{e}-011 \\ \mathrm{Pu}-238 & 7.9070 \mathrm{e}-016 \\ \mathrm{Pu}-239 & 1.1255 \mathrm{e}-016 \\ \mathrm{Pu}-240 & 9.6377 \mathrm{e}-018 \\ \mathrm{Pu}-241 & 1.8212 \mathrm{e}-016 \\ \mathrm{Sr}-90 & 1.9343 \mathrm{e}-013 \\ \text { Tc-99 } & 5.1695 \mathrm{e}-016 \\ \mathrm{Y}-90 & 1.9343 \mathrm{e}-013\end{array}$

becquerels

3.2269e-006

$\underline{\mathrm{Ci} / \mathrm{cm}^{3}}$

$\mathrm{Bq} / \mathrm{cm}^{3}$

8.2033e-002

7.7100e-017

$2.8527 \mathrm{e}-012$

8.9567e-002

$1.9600 \mathrm{e}-012$

$7.2520 \mathrm{e}-008$

$6.0269 \mathrm{e}-001$

2.1400e-012

7.9180e-008

$2.9256 \mathrm{e}-005$

$1.4400 \mathrm{e}-011$

$5.3280 \mathrm{e}-007$

$4.1645 \mathrm{e}-006$

$6.9900 \mathrm{e}-016$

$2.5863 \mathrm{e}-011$

$3.5659 \mathrm{e}-007$

$9.9500 \mathrm{e}-017$

$3.6815 \mathrm{e}-012$

8.5200e-018

$3.1524 \mathrm{e}-013$

$6.7385 \mathrm{e}-006$

$1.6100 \mathrm{e}-016$

$5.9570 \mathrm{e}-012$

7.1570e-003

$1.7100 \mathrm{e}-013$

6.3270e-009

$1.9127 \mathrm{e}-005$

$4.5700 \mathrm{e}-016$

$1.6909 \mathrm{e}-011$

$7.1570 \mathrm{e}-003$

$1.7100 \mathrm{e}-013$

6.3270e-009

The material reference is : Source

X Direction

Y Direction

Z Direction

\section{Integration Parameters}

\section{Results}


Page : 2

DOS File : FT3-1115.MS5

Run Date : January 7, 2002

Run Time: 13:50:58

Duration : 00:00:14

\begin{tabular}{|c|c|c|c|c|c|}
\hline $\begin{array}{l}\text { Energy } \\
\underline{\mathrm{MeV}}\end{array}$ & $\begin{array}{c}\text { Activity } \\
\text { photons/sec }\end{array}$ & $\frac{\text { Fluence Rate }}{\mathrm{MeV} / \mathrm{cm}^{2} / \mathrm{sec}}$ & $\frac{\text { Fluence Rate }}{\mathrm{MeV} / \mathrm{cm}^{2} / \mathrm{sec}}$ & $\frac{\text { Exposure Rate }}{\underline{\mathrm{mR} / \mathrm{hr}}}$ & $\frac{\text { Exposure Rate }}{\mathrm{mR} / \mathrm{hr}}$ \\
\hline & & No Buildup & With Buildup & No Buildup & With Buildup \\
\hline 0.015 & $2.692 \mathrm{e}-06$ & $4.154 \mathrm{e}-45$ & $1.931 \mathrm{e}-38$ & $3.563 e-46$ & $1.656 \mathrm{e}-39$ \\
\hline 0.02 & $1.466 \mathrm{e}-06$ & $7.580 \mathrm{e}-28$ & $2.775 e-27$ & $2.626 \mathrm{e}-29$ & $9.614 \mathrm{e}-29$ \\
\hline 0.03 & $4.271 \mathrm{e}-01$ & $2.560 \mathrm{e}-12$ & $2.347 \mathrm{e}-11$ & $2.538 \mathrm{e}-14$ & $2.327 \mathrm{e}-13$ \\
\hline 0.04 & 4.646e-02 & $1.779 \mathrm{e}-10$ & $2.509 \mathrm{e}-09$ & $7.868 \mathrm{e}-13$ & $1.109 \mathrm{e}-11$ \\
\hline 0.05 & $1.057 \mathrm{e}-09$ & $5.530 \mathrm{e}-17$ & $7.363 \mathrm{e}-16$ & $1.473 \mathrm{e}-19$ & $1.961 \mathrm{e}-18$ \\
\hline 0.06 & $1.153 \mathrm{e}-06$ & $2.253 \mathrm{e}-13$ & $2.265 \mathrm{e}-12$ & $4.475 \mathrm{e}-16$ & $4.499 \mathrm{e}-15$ \\
\hline 0.08 & $8.075 \mathrm{e}-10$ & $5.654 \mathrm{e}-16$ & $2.922 \mathrm{e}-15$ & $8.948 \mathrm{e}-19$ & $4.624 \mathrm{e}-18$ \\
\hline 0.1 & $4.289 \mathrm{e}-09$ & $5.568 \mathrm{e}-15$ & $1.804 \mathrm{e}-14$ & $8.518 \mathrm{e}-18$ & $2.760 \mathrm{e}-17$ \\
\hline 0.15 & $7.529 \mathrm{e}-10$ & $2.045 \mathrm{e}-15$ & $4.034 \mathrm{e}-15$ & $3.368 \mathrm{e}-18$ & $6.642 \mathrm{e}-18$ \\
\hline 0.2 & $6.986 \mathrm{e}-11$ & $2.802 \mathrm{e}-16$ & $4.454 \mathrm{e}-16$ & $4.946 \mathrm{e}-19$ & $7.861 \mathrm{e}-19$ \\
\hline 0.3 & $9.921 \mathrm{e}-11$ & $6.448 \mathrm{e}-16$ & $8.908 \mathrm{e}-16$ & $1.223 \mathrm{e}-18$ & $1.690 \mathrm{e}-18$ \\
\hline 0.4 & $2.184 \mathrm{e}-10$ & $1.963 \mathrm{e}-15$ & $2.540 \mathrm{e}-15$ & $3.824 \mathrm{e}-18$ & $4.949 \mathrm{e}-18$ \\
\hline 0.5 & $1.184 \mathrm{e}-11$ & $1.362 \mathrm{e}-16$ & $1.694 \mathrm{e}-16$ & $2.674 \mathrm{e}-19$ & $3.326 \mathrm{e}-19$ \\
\hline 0.6 & $7.365 \mathrm{e}-02$ & $1.035 \mathrm{e}-06$ & $1.253 \mathrm{e}-06$ & $2.019 \mathrm{e}-09$ & $2.445 \mathrm{e}-09$ \\
\hline 0.8 & $2.425 \mathrm{e}-11$ & $4.660 \mathrm{e}-16$ & $5.438 \mathrm{e}-16$ & $8.864 \mathrm{e}-19$ & $1.034 \mathrm{e}-18$ \\
\hline 1.0 & $1.100 \mathrm{e}-12$ & $2.693 \mathrm{e}-17$ & $3.076 \mathrm{e}-17$ & $4.964 \mathrm{e}-20$ & $5.669 \mathrm{e}-20$ \\
\hline OTALS: & $5.472 \mathrm{e}-01$ & $1.035 \mathrm{e}-06$ & $1.255 \mathrm{e}-06$ & $2.020 \mathrm{e}-09$ & $2.456 \mathrm{e}-09$ \\
\hline
\end{tabular}


Page : 1

DOS File : GAC11-15.MS5

Run Date : January 7, 2002

Run Time: 13:54:45

Duration : 00:00:33
File Ref:

Date:

By:

Checked:

Case Title: GAC Disposal

Description: Activated Carbon in Drum -- 11/15/01

Geometry: 7 - Cylinder Volume - Side Shields

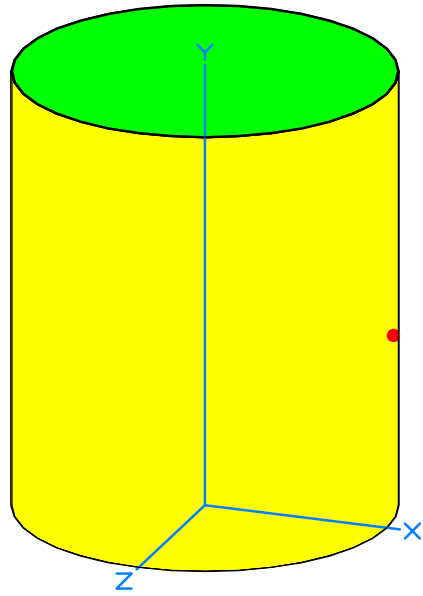

Source Dimensions

Height

Radius

$69.84 \mathrm{~cm}$

$29.21 \mathrm{~cm}$

$2 \mathrm{ft} 3.5$ in

11.5 in

Dose Points

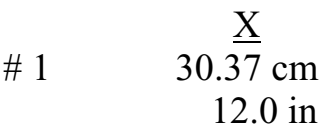

\section{$\underline{\mathrm{Y}}$} $31.04 \mathrm{~cm}$

$1 \mathrm{ft} 0.2$ in
$0 \underline{\mathrm{Z}}$

0.0 in

\begin{tabular}{|c|c|c|c|}
\hline \multicolumn{4}{|c|}{ Shields } \\
\hline Shield Name & Dimension & Material & Density \\
\hline Source & $1.87 \mathrm{e}+05 \mathrm{~cm}^{3}$ & Carbon & 0.55 \\
\hline Shield 1 & $.16 \mathrm{~cm}$ & Iron & 7.86 \\
\hline Transition & $1.0 \mathrm{~cm}$ & Air & 0.00122 \\
\hline Air Gap & & Air & 0.00122 \\
\hline
\end{tabular}

Source Input

Grouping Method : Standard Indices

Number of Groups : 25

Lower Energy Cutoff : 0.015

Photons $<0.015$ : Excluded

Library : ICRP-38

\begin{tabular}{|c|c|c|c|c|}
\hline$\underline{\text { Nuclide }}$ & $\underline{\text { curies }}$ & becquerels & $\underline{\mu \mathrm{Ci} / \mathrm{cm}^{3}}$ & $\underline{\mathrm{Bq} / \mathrm{cm}^{3}}$ \\
\hline Am-241 & $2.4149 \mathrm{e}-017$ & $8.9353 \mathrm{e}-007$ & $1.2900 \mathrm{e}-016$ & $4.7730 \mathrm{e}-012$ \\
\hline $\mathrm{Ba}-137 \mathrm{~m}$ & $6.1403 e-013$ & $2.2719 \mathrm{e}-002$ & $3.2800 \mathrm{e}-012$ & $1.2136 \mathrm{e}-007$ \\
\hline Cs-137 & $6.7019 \mathrm{e}-013$ & $2.4797 \mathrm{e}-002$ & $3.5800 \mathrm{e}-012$ & $1.3246 \mathrm{e}-007$ \\
\hline $\mathrm{I}-129$ & $4.4742 \mathrm{e}-010$ & $1.6555 \mathrm{e}+001$ & $2.3900 \mathrm{e}-009$ & $8.8430 \mathrm{e}-005$ \\
\hline $\mathrm{Pu}-238$ & $2.1903 e-016$ & $8.1041 \mathrm{e}-006$ & $1.1700 \mathrm{e}-015$ & $4.3290 \mathrm{e}-011$ \\
\hline $\mathrm{Pu}-239$ & $3.1263 \mathrm{e}-017$ & $1.1567 \mathrm{e}-006$ & $1.6700 \mathrm{e}-016$ & $6.1790 \mathrm{e}-012$ \\
\hline $\mathrm{Pu}-240$ & $2.6770 \mathrm{e}-018$ & $9.9050 \mathrm{e}-008$ & $1.4300 \mathrm{e}-017$ & $5.2910 \mathrm{e}-013$ \\
\hline $\mathrm{Pu}-241$ & $5.0545 \mathrm{e}-017$ & $1.8702 \mathrm{e}-006$ & $2.7000 \mathrm{e}-016$ & $9.9900 \mathrm{e}-012$ \\
\hline Sr-90 & $5.3728 \mathrm{e}-014$ & $1.9879 \mathrm{e}-003$ & $2.8700 \mathrm{e}-013$ & $1.0619 \mathrm{e}-008$ \\
\hline Tc-99 & $1.4359 \mathrm{e}-016$ & $5.3127 e-006$ & $7.6700 \mathrm{e}-016$ & $2.8379 \mathrm{e}-011$ \\
\hline$Y-90$ & $5.3728 \mathrm{e}-014$ & $1.9879 \mathrm{e}-003$ & $2.8700 \mathrm{e}-013$ & $1.0619 \mathrm{e}-008$ \\
\hline
\end{tabular}

Buildup

The material reference is : Source

Radial

Integration Parameters

Circumferential

Y Direction (axial)

\section{Results}


Page : 2

DOS File : GAC11-15.MS5

Run Date : January 7, 2002

Run Time: 13:54:45

Duration : 00:00:33

\begin{tabular}{|c|c|c|c|c|c|}
\hline $\begin{array}{l}\text { Energy } \\
\underline{\mathrm{MeV}}\end{array}$ & $\begin{array}{c}\text { Activity } \\
\text { photons/sec }\end{array}$ & $\frac{\text { Fluence Rate }}{\mathrm{MeV} / \mathrm{cm}^{2} / \mathrm{sec}}$ & $\frac{\text { Fluence Rate }}{\mathrm{MeV} / \mathrm{cm}^{2} / \mathrm{sec}}$ & $\frac{\text { Exposure Rate }}{\underline{\mathrm{mR} / \mathrm{hr}}}$ & $\frac{\text { Exposure Rate }}{\mathrm{mR} / \mathrm{hr}}$ \\
\hline & & No Buildup & With Buildup & No Buildup & With Buildup \\
\hline 0.015 & $7.462 \mathrm{e}-07$ & $1.482 \mathrm{e}-46$ & $3.568 \mathrm{e}-38$ & $1.271 \mathrm{e}-47$ & $3.061 \mathrm{e}-39$ \\
\hline 0.02 & $4.061 \mathrm{e}-07$ & $5.096 \mathrm{e}-29$ & $7.562 \mathrm{e}-28$ & $1.765 e-30$ & $2.620 \mathrm{e}-29$ \\
\hline 0.03 & $1.160 \mathrm{e}+01$ & $2.761 \mathrm{e}-11$ & $1.303 \mathrm{e}-09$ & $2.736 \mathrm{e}-13$ & $1.291 \mathrm{e}-11$ \\
\hline 0.04 & $1.244 \mathrm{e}+00$ & $2.430 \mathrm{e}-09$ & $1.771 \mathrm{e}-07$ & $1.075 \mathrm{e}-11$ & $7.832 \mathrm{e}-10$ \\
\hline 0.05 & $2.936 \mathrm{e}-10$ & $9.202 \mathrm{e}-18$ & $5.800 \mathrm{e}-16$ & $2.451 \mathrm{e}-20$ & $1.545 \mathrm{e}-18$ \\
\hline 0.06 & $3.194 \mathrm{e}-07$ & $4.168 \mathrm{e}-14$ & $1.930 \mathrm{e}-12$ & $8.279 \mathrm{e}-17$ & $3.834 \mathrm{e}-15$ \\
\hline 0.08 & $2.236 \mathrm{e}-10$ & $1.195 \mathrm{e}-16$ & $3.022 \mathrm{e}-15$ & $1.890 \mathrm{e}-19$ & $4.782 \mathrm{e}-18$ \\
\hline 0.1 & $1.188 \mathrm{e}-09$ & $1.273 \mathrm{e}-15$ & $2.026 \mathrm{e}-14$ & $1.947 \mathrm{e}-18$ & $3.100 \mathrm{e}-17$ \\
\hline 0.15 & $2.088 \mathrm{e}-10$ & $5.258 \mathrm{e}-16$ & $4.166 \mathrm{e}-15$ & $8.659 \mathrm{e}-19$ & $6.860 \mathrm{e}-18$ \\
\hline 0.2 & $1.938 \mathrm{e}-11$ & $7.805 \mathrm{e}-17$ & $4.322 \mathrm{e}-16$ & $1.377 \mathrm{e}-19$ & $7.629 \mathrm{e}-19$ \\
\hline 0.3 & $2.753 e-11$ & $2.013 \mathrm{e}-16$ & $7.662 \mathrm{e}-16$ & $3.818 \mathrm{e}-19$ & $1.453 \mathrm{e}-18$ \\
\hline 0.4 & $6.065 \mathrm{e}-11$ & $6.658 \mathrm{e}-16$ & $2.032 \mathrm{e}-15$ & $1.297 \mathrm{e}-18$ & $3.959 \mathrm{e}-18$ \\
\hline 0.5 & $3.287 e-12$ & $4.927 \mathrm{e}-17$ & $1.301 \mathrm{e}-16$ & $9.672 \mathrm{e}-20$ & $2.553 \mathrm{e}-19$ \\
\hline 0.6 & $2.040 \mathrm{e}-02$ & $3.937 \mathrm{e}-07$ & $9.416 \mathrm{e}-07$ & $7.686 \mathrm{e}-10$ & $1.838 \mathrm{e}-09$ \\
\hline 0.8 & $6.716 \mathrm{e}-12$ & $1.927 \mathrm{e}-16$ & $3.893 \mathrm{e}-16$ & $3.664 \mathrm{e}-19$ & $7.405 \mathrm{e}-19$ \\
\hline 1.0 & $3.047 \mathrm{e}-13$ & $1.186 \mathrm{e}-17$ & $2.168 \mathrm{e}-17$ & $2.186 \mathrm{e}-20$ & $3.997 \mathrm{e}-20$ \\
\hline OTALS: & $1.286 \mathrm{e}+01$ & $3.962 \mathrm{e}-07$ & $1.120 \mathrm{e}-06$ & $7.796 \mathrm{e}-10$ & $2.634 \mathrm{e}-09$ \\
\hline
\end{tabular}




\section{APPENDIX D}

\section{MERCURY CONCENTRATIONS}



+
4
$\frac{4}{0}$
$\stackrel{0}{0}$
0
0

은 흔

穴

오 오

이 일

요 8

仓ิ ल

음

II II

은 능

${ }^{m} \varepsilon{ }^{m} \varepsilon$

후 음

조 조

ह ह

กิ

峑

仓

은

$-0$
告

告

${ }^{m} E{ }^{m} E$

오 우

오 오

일

두움

山े ய்

ஸे

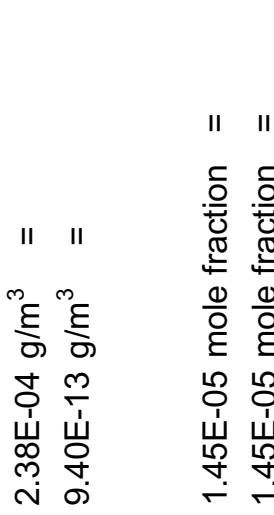

II II

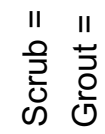

. $\subseteq$

등 음

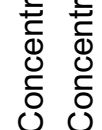

오 오
先

曹告告

${ }^{\infty} E{ }^{\infty} E \quad$

오ㅇㅗㅗ 오

ह ह

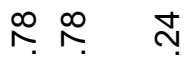

$\stackrel{\infty}{\stackrel{m}{m}} \stackrel{\infty}{\square}$

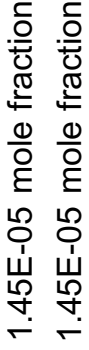

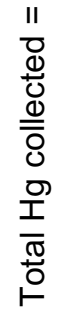

㐫

${ }^{m} E{ }^{m} E$

우 오

일 일

○)

岁

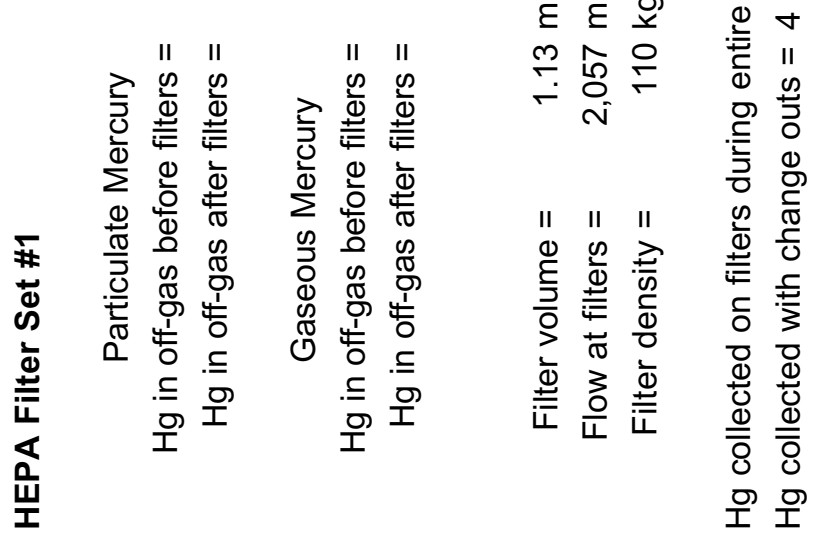


$\checkmark$
4
0
$N$
0
0
0
0

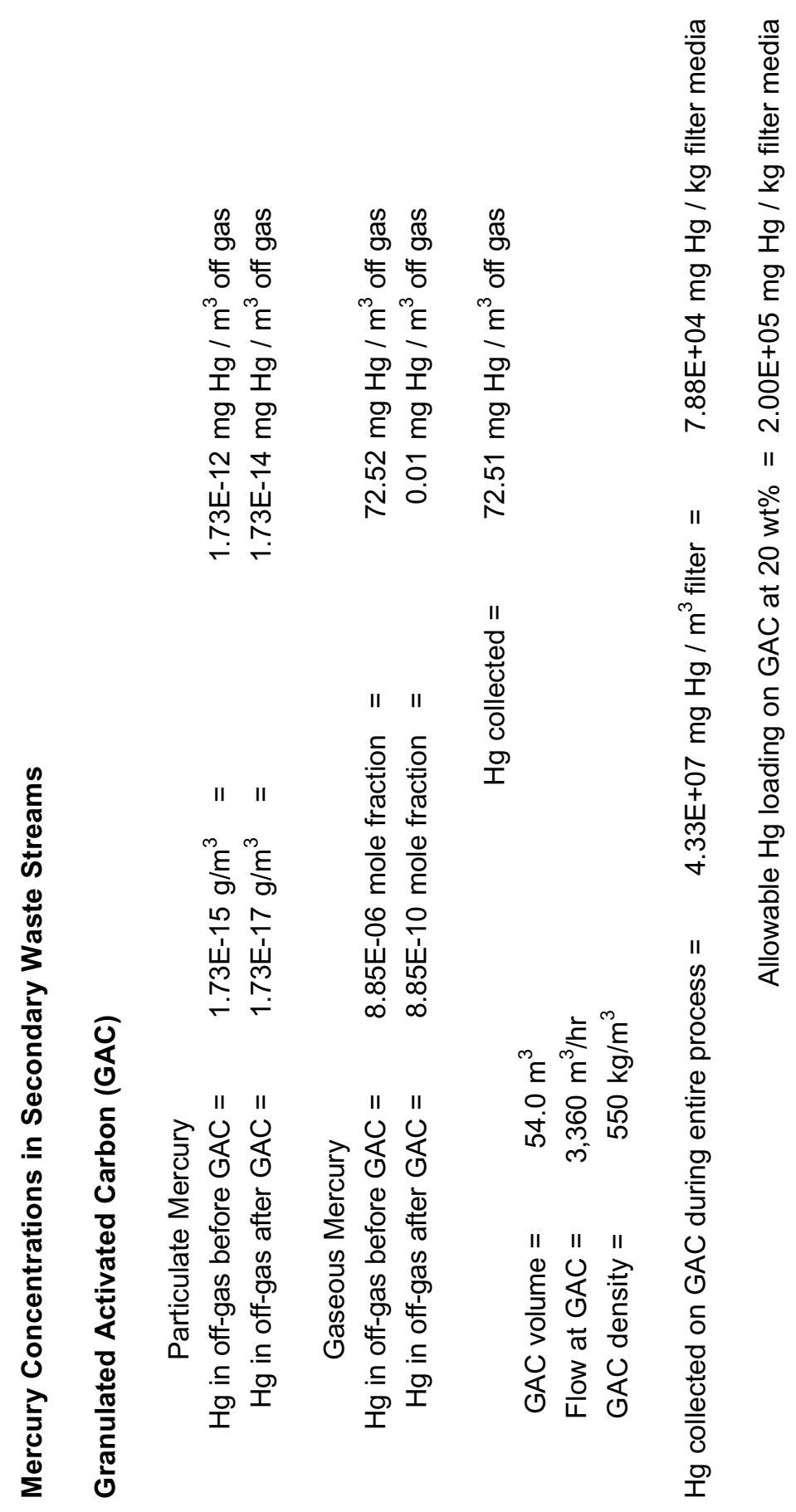


7
4
0
0
0
0
0

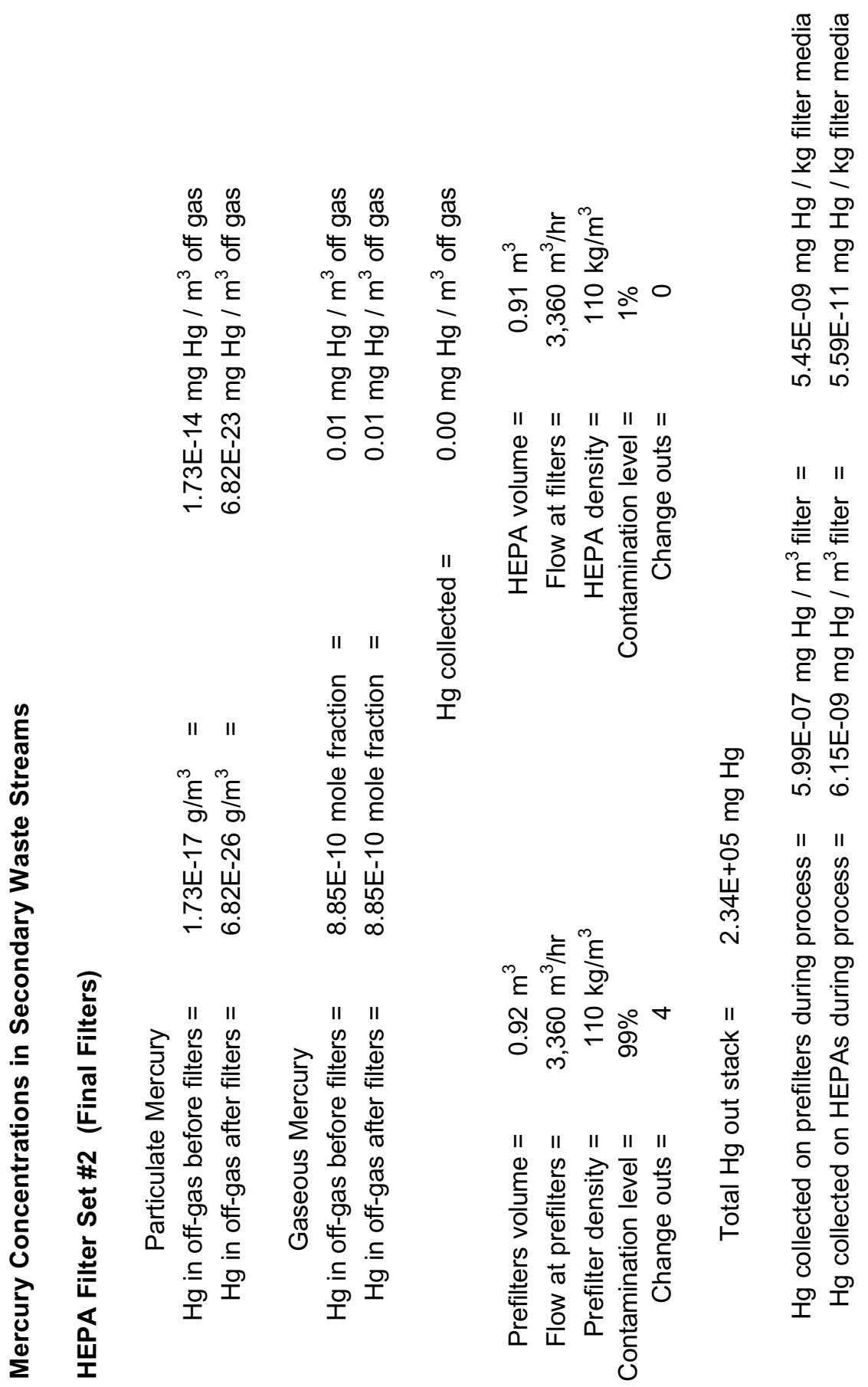




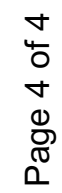

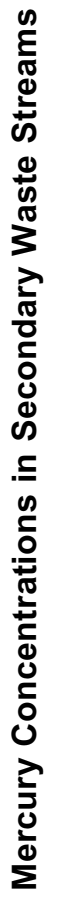

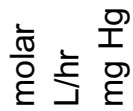

กำ 옹

嵌岀

ल

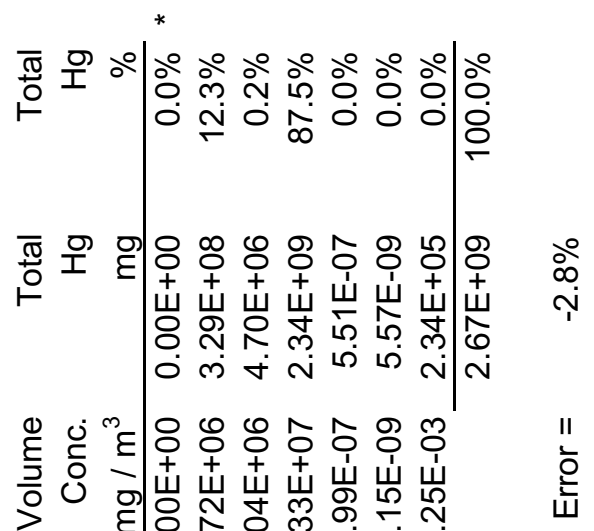

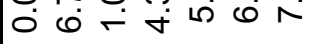

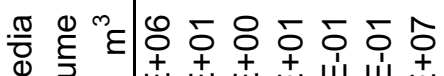

山岀岀岀岀

位

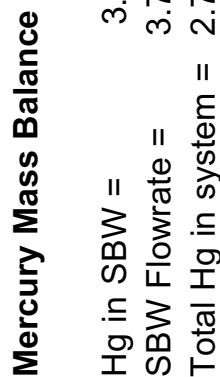

II II II II II || ||

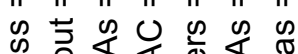

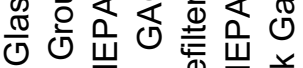

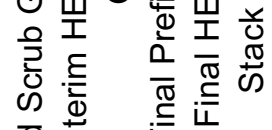

오

हे

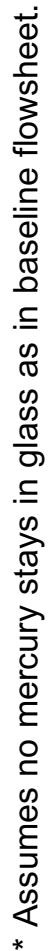

